"Approved for public release; distribution is

FEB 1. 1902 unlimited."

\title{
Dungeness Crab Survey for the Southwest Ocean Disposal Site and Additional Sites off Grays Harbor, Washington, June 1991
}

\author{
L. D. Antrim \\ V. I. Cullinan \\ W. H. Pearson \\ Battelle/Marine Sciences Laboratory \\ Sequim, Washington
}

January 1992

Prepared for the

U.S. Army Corps of Engineers - Seattle District under a Related Services Agreement with the U.S. Department of Energy

Contract DE-AC06-76RLO 1830

Pacific Northwest Laboratory

Operated for the U.S. Department of Energy

by Battelle Memorial Institute 


\title{
DISCLAIMER
}

This report was prepared as an account of work sponsored by an agency of the United States Government. Neither the United States Government nor any agency thereof, nor Battelle Memorial Institute, nor any of their employees, makes any warranty, expressed or implied, or assumes any legal liability or responsibility for the accuracy, completeness, or usefulness of any information, apparatus, product, or process disclosed, or represents that its use would not infringe privately owned rights. Reference herein to any specific commercial product, process, or service by trade name, trademark, manufacturer, or otherwise does not necessarily constitute or imply its endorsement, recommendation, or favoring by the United States Government or any agency thereof, or Battelle Memorial Institute. The views and opinions of authors expressed herein do not necessarily state or reflect those of the United States Government or any agency thereof.

\author{
PACIFIC NORTHWEST L.ABORATORY \\ operated by \\ BATTELLE MEMORIAL INSTITUTE \\ for the \\ UNITED STATES DEPARTMENT OF ENERGY \\ under Contract DE-ACO6-76RLO 1830
}

Printed in the United States of America

Available to DOE and DOE contractors from the

Office of Scientific and Technical Information, P.O. Box 62, Oak Ridge, IN 37831;

prices available from (615) 576-8401. FTS 626-8401.

Available to the public from the National Technical Information Service,

U.S. Department of Commerce, 5285 Port Royal Rd., Springfield, VA 22161 
PNL- -7932

DE92 007513

DUNGENESS CRAB SURVEY FOR THE SOUTHWEST

OCEAN DISPOSAL SITE AND ADDITIONAL SITES

OFF GRAYS HARBOR, WASHINGTON, JUNE 1991

L. D. Antrim

V. I. Cullinan

W. H. Pearson

Battelle/Marine Sciences Laboratory

Sequim, Washington

January 1992

Prepared for the

U.S. Army Corps of Engineers -

Seattle District

under a Related Services Agreement

with the U.S. Department of Energy

Contract DE-ACO6-76RLO 1830

Pacific Northwest Laboratory

Richland, Washington 99352 


\section{EXECUTIVE SUMMARY}

As part of the Grays Harbor Navigation Improvement Project, the U.S. Army Corps of Engineers, Seattle District (USACE), has made active use of the Southwest Ocean Disposal Site off Grays Harbor, Washington. Disposal site boundaries were established to avoid an area where high densities of Young-ofthe-Year (YOY) Dungeness crab, Cancer magister, were observed during the site selection surveys. To monitor possible impacts of disposal operations on Dungeness crab at the site, USACE recommended a crab distribution survey prior to disposal operations in the February 1989 environmental impact statement supplement (EISS) as part of a tiered monitoring strategy for the site. According to the tiered monitoring strategy, a preliminary survey is conducted to determine if the disposal site contains an exceptionally high density of YoY Dungeness crab. The trigger for moving to a more intensive sampling effort is a YOY crab density within the disposal site that is 100 times higher than the density in the reference area to the north. This report concerns a 1991 survey that was designed to verify that the density of Yor Dungeness crab present at the disposal site was not exceptionally high. Another objective of the survey was to estimate Dungeness crab densities at nearshore areas that are being considered as sediment berm sites by USACE.

In June 1991, the mean density of YoY Dungeness crab was $1,922( \pm 1,862)$ crab/ha within the Southwest Ocean Disposal Site (based on 5 trawls) and 8,808 $( \pm 9,783) \mathrm{crab} / \mathrm{ha}$ in the north reference area (also based on 5 trawls). These results indicate that an area of exceptional crab density has not developed on the Southwest Ocean Disposal Site. Survey data from June 1991 confirm that the disposal site boundaries remain appropriate, and that there is no need to move to the second monitoring tier.

For the two proposed sediment berm sites, South Beach and Half Moon Bay, trawl catches of Dungeness crab or other major macroepifaunal taxa were similar to catches from other areas sampled for this survey. No unique populations of macroepifauna were found at the proposed sediment berm sites. Surface sediment samples at these sites were fine-grained sand. Adult and $1^{+}$ age class Dungeness crab were found at higher densities in Grays Harbor Entrance than in the areas sampled outside Grays Harbor. Megalopal larvae of 
Dungeness crab were abundant in trawls at or near the Southwest Ocean Disposal Site and at Half Moon Bay. However, the megalopae may have been collected from the water column, and, in fact, were seen swimming in surface waters at Half Moon Bay on two days between June 18 and 21, 1991. 


\section{ACKNOWLEDGMENTS}

The authors are indebted to Bruce Higgins, who provided invaluable assistance with organizing the project, preparing field gear, outfitting the vessel for sampling, and training personnel for the field work. Ray Bienert and Tom Parkwell proved to be efficient field personnel who contributed significantly to the success of the operations. Field sampling was greatly simplified by the expert advice, local knowledge, and support of Vern and Leif Heikkila, the skipper and deck hand on the FV Karelia. The Technical Representative from USACE, Seattle District, was Bert Brun, who fostered a amiable working relationship. Ron Thom assisted with a review of this report. 


\section{CONTENTS}

EXECUTIVE SUMMARY ................... ACKNOWLEDGMENTS ....................

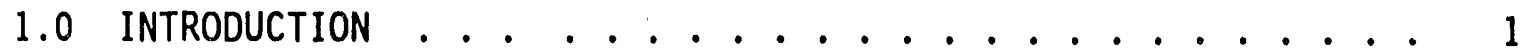

1.1 OBJECTIVES . . . . . . . . . . . . . 1

1.2 STUDY SITES .................... 4

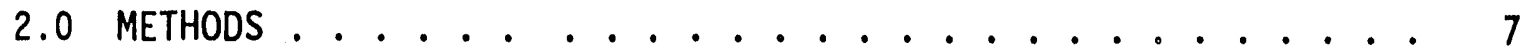

3.0 RESULTS AND DISCUSSION ................ 11

3.1 TRAWL CATCHES ...................... 11

3.1.1 Southwest Ocean Disposal Site ........ 17

3.1.2 North Reference Area

for the Southwest Ocean Disposal Site . . . . . 17

3.1.3 Comparison of YOY Dungeness Crab Catches from
Offshore Sites . . . . 17

3.1.4 South Beach Berm Site ............ 18

3.1.5 Half Moon Bay Berm Site . . . . . . . . 18

3.2 SEDIMENT GRAB SAMPLES . . . . . . . . . . . . 19

3.3 HYDROGRAPHIC PROFILES . . . . . . . . . . . . 19

4.0 CONCLUSIONS . . . . . . . . . . . . . . 21

5.0 REFERENCES ......................... 23

APPENDIX A - STATION LIST AND TRAWL INFORMATION . . . . . . . A.I

APPENDIX B - DUNGENESS CRAB CATCH DATA .......... B. 1

APPENDIX C - TRALL CATCH DATA ............. c.

APPENDIX D - SEDIMENT GRAIN SIZE ANALYSIS . . . . . . . . D.1

APPENDIX E - HYDROGRAPHIC PROFILES ............ E.1 


\section{FIGURES}

1.1 Location of Grays Harbor and the Study Area ....... 2

1.2 The Southwest Ocean Disposal Site for Dredged Materials

from the Grays Harbor Bar Channel ............ 3

3.1 Locations for the Trawling Stations in June $1991 \ldots 12$

3.2 Mean Density of Dungeness Crab from Nearshore and Offshore Areas Sampled in June 1991 .......... 14

3.3 Density of YoY Dungeness Crab Over Depth from June 1985, 1990, and 1991 Surveys at Grays Harbor, Washington, as

Percent of Maximum Catch for the Year ......... 15

D.1 Grain Size Analysis from South Beach Site,

Grays Harbor, Washington, June 1991 ......... D.2

D.2 Grain Size Analysis from Half Moon Bay Site,

Grays Harbor, Washington, June 1991 . . . . . . . D.5

D.3 Grain Size Analysis from Half Moon Bay and North

Entrance Sites, Grays Harbor, Washington, June 1991 . . . D.6

E.1 Hydrographic Data from the Southwest Ocean Disposal Site

Collected on June 20 and $21,1991 \ldots \ldots$ E.3

E.2 Hydrographic Data from the North Reference Area for the Southwest Ocean Disposal Site Collected on June 20 and

E.3 Hydrographic Data from the Proposed South Beach Berm Site Collected on June 19,1991 ............. E.5

E.4 Hydrographic Data from Grays Harbor Entrance Collected on June 18 and 21, 1991 at Haif Moon Bay and North Entrance Sites 


\section{TABLES}

3.1 Dungeness Crab Catch Data from Bottom Trawls Conducted

for the June 1991 Grays Harbor Crab Survey. . . . . . . . . 13

A.1 Station List and Trawl Information for the June 1991

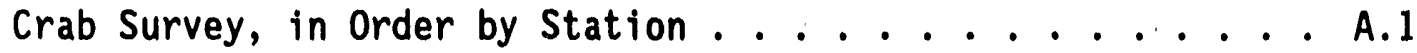

B.1 Catch Data for Adult Dungeness Crab from Trawls

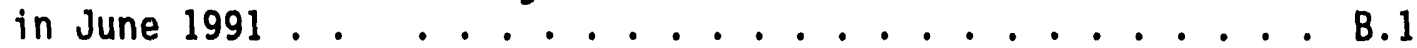

B.2 Catch Data for $\mathrm{O}^{+}$and $\mathrm{1}^{+}$Age $\mathrm{Class}$ Dungeness Crab from

Trawls in June 1991 in $\mathrm{kg} / \mathrm{ha} \ldots \ldots .2$

C.1 Trawl Catch Data from June 1991 Crab Survey. . . . . . . . . C.1

D.1 Grain Size Analysis of Sediment Grab Samples Collected

in June 1991 from the Grays Harbor Area. . . . . . . . . . D.1

E.1 Hydrographic Data from Sites Near Grays Harbor, Washington, Collected for the 1991 Dungeness Crab

Survey Between June 18 and $21,1991 \ldots \ldots .1$ 


\subsection{INTRODUCTION}

As part of the Grays Harbor Navigation Improvement Project, the U.S. Army Corps of Engineers, Seattle District (USACE), has made active use of the Southwest Ocean Disposal Site off Grays Harbor, Washington (Figure 1.1). To monitor possible impacts of dredged material disposal on Dungeness crab, Cancer magister, at the Southwest Ocean Disposal Site (Figure 1.2), a survey of crab distribution prior to disposal operations was recommended in the February 1989 environmental impact statement supplement (EISS) (USACE 1989). A spring 1985 crib survey had found high concentrations of Young-of-the-Year (YOY) Dungeness crab, as well as smaller numbers of adult crabs, especially between the 100- and 120-foot contours southwest of the harbor entrance (Pearson et al. 1987). Based on the 1985 survey, the disposal site was located farther south to avoid the area of high crab concentrations.

The EISS incorporated elements from the 1987 Site Monitoring Plan developed by Battelle/Marine Sciences Laboratory (MSL), in which a tiered approach to disposal site monitoring was recommended (Pearson 1987). Under Tier 1 in the Site Monitoring $\mathrm{Plan}$, crab densities are monitored to confirm that the disposal site does not contain an exceptionally high density of YoY Dungeness crab. The trigger for moving to Tier 2 of the evaluation, which entails an increased sampling effort to determine whether a change in disposal operations is needed, is a YOY crab density within the disposal site that is 100 times higher than the density in the reference area to the north, where high crab concentrations were found in the spring of 1985. A June 1990 survey found acceptably low numbers of juvenile crabs inside the disposal site, and disposal operations proceeded as scheduled. The June 1991 survey was intended to verify the selection of the original disposal site, so that planned disposal of materials dredged from the Grays Harbor Bar Channel in 1991 will not significantly affect crab populations.

\subsection{OBJECTIVES}

The survey of Dungeness crab distribution in June 1991 was conducted to estimate Dungeness crab densities at two general areas: 1) at and near the Southwest Ocean Disposal Site, and 2) in nearshore areas being considered as 


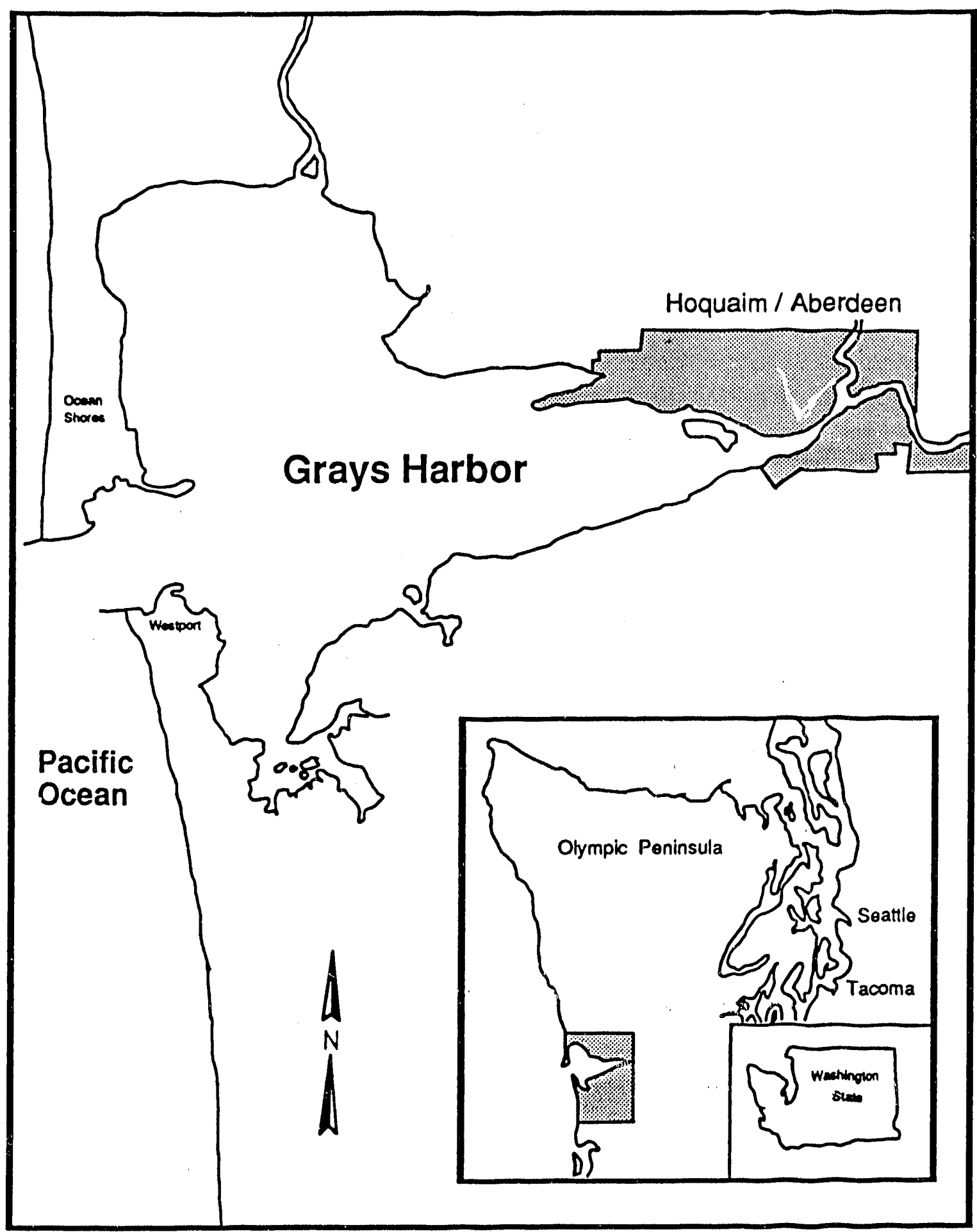

FIGURE 1.1. Location of Grays Harbor and the Study Area 


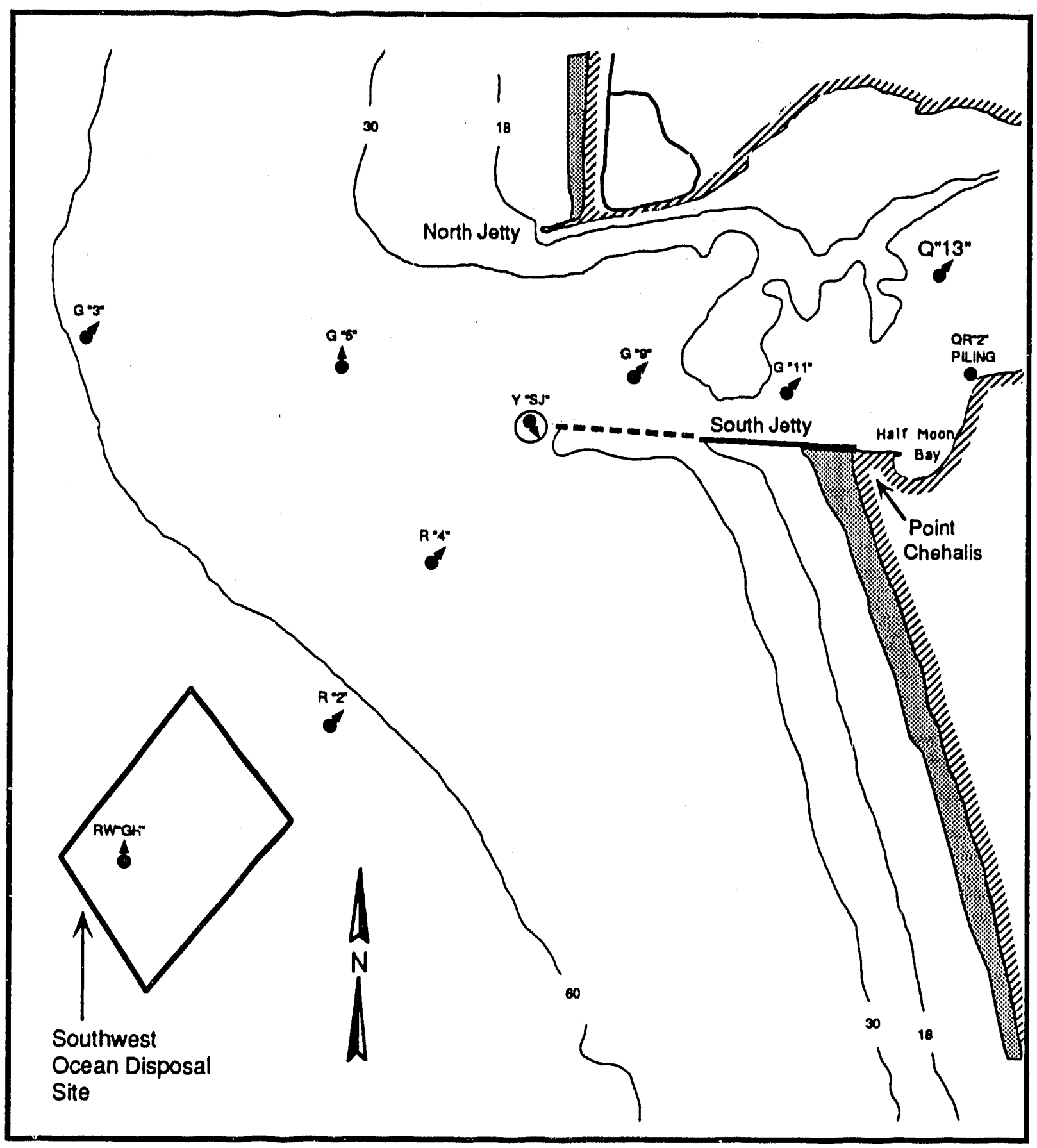

FIGURE 1.2. The Southwest Ocean Disposal Site for Dredged Materials from the Grays Harbor Bar Channel (depth contours are in feet) 
sediment berm sites by USACE. The primary objective of this survey was to determine whether YOY Dungeness crab are present at, or near, the Southwest Ucean Disposal Site at densities that would require changes in scheduled 1991 operations to dispose of dredged material. A secondary objective was to provide preliminary information on Dungeness crab densities and surface sediment characteristics at the South Beach and Half Moon Bay sites, where construction of sediment berms is proposed by USACE. These sediments would accrete in areas that have undergone extensive erosion in recent years (i.e., the shoreward end of the South Jetty).

\subsection{STUDY SITES}

The Southwest Ocean Disposal Site is centered near the Southwest Navigational Lane Buoy "GH", which is located approximately 4 miles southsouthwest of the nouth of Grays Harbor. The Southwest Ocean Disposal Site has the shape of a parallelogram and covers 2 square miles in area (Figure 1.2). The site corners, as given in the EISS (USACE 1989; Page 2-14), are

\begin{tabular}{cccc} 
CORNER & LATITUDE & & LONGITUDE \\
\cline { 2 - 3 } NE & $46^{\circ} 52.94^{\prime} \mathrm{N}$ & & $124^{\circ} 13.81^{\prime} \mathrm{W}$ \\
SE & $46^{\prime} 52.17^{\prime} \mathrm{N}$ & & $124^{\circ} 12.96^{\prime} \mathrm{W}$ \\
SW & $46^{\circ} 51.15^{\prime} \mathrm{N}$ & & $124^{\circ} 14.19^{\prime} \mathrm{W}$ \\
NW & $46^{\circ} 51.92^{\prime} \mathrm{N}$ & & $124^{\circ} 14.95^{\prime} \mathrm{W}$
\end{tabular}

Sampling was also conducted north of the disposal site, in the area where high concentrations of YOY Dungeness were found in 1985. Trawls were made within 1.5 nautical miles of the northern boundary of the disposal site, and over the same depth contours as at the disposal site.

The two nearshore areas under consideration for sediment berm sites are the South Beach site and Half Moon Bay site (Figure 1.2). The South Beach site is located outside Grays Harbor approximately 1.5 miles south-southeast of Point Chehalis, between the 30- and 46- ft depth contours. The corners of the South Beach study area as defined in the USACE work request to MSL were 
CORNER

NE

SE

SW

NW

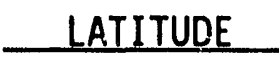

$46^{\circ} 53.58^{\prime} \mathrm{N}$

$46^{\circ} 53.01^{\prime} \mathrm{N}$

$46^{\circ} 52.46^{\prime} \mathrm{N}$

$46^{\circ} 53.42^{\prime} \mathrm{N}$
LONGITUDE

$124^{\circ} 09.11^{\prime} \mathrm{W}$

$124^{\circ} 08.44^{\prime} \mathrm{W}$

$124^{\circ} 09.52^{\prime} \mathrm{W}$

$124^{\circ} 10.20^{\prime} \mathrm{W}$

The Half Moon Bay site is located along the south shore of Grays Harbor Entrance between the 16- and 24-ft depth contours shown on oceanographic charts. Half Moon Bay is exposed to strong wave energy and tidal currents, so that accretion and erosion of the sediments results in periodic variation of water depthis in this area. Therefore, local geography at the site was considered more important than water depth in determining the position of trawls. The corners of the Half Moon Bay study area as defined in the USACE work request to MSL were

\begin{tabular}{|c|c|c|}
\hline CORNER & LATITUDE & LONGITUDE \\
\hline NE & $46^{\circ} 54.41^{\prime} \mathrm{N}$ & $124^{\circ} 07.32^{\prime} \mathrm{W}$ \\
\hline SE & $46^{\circ} 54.34^{\prime} \mathrm{N}$ & $124^{\circ} 07.23^{\prime} \mathrm{W}$ \\
\hline SW & $46^{\circ} 54.21^{\prime} \mathrm{N}$ & $124^{\circ} 07.44^{\prime} \mathrm{W}$ \\
\hline NW & $46^{\circ} 54.28^{\prime} \mathrm{N}$ & $124^{\circ} 07.54^{\prime} \mathrm{W}$ \\
\hline
\end{tabular}

The North Entrance site (Figure 1.2), on the north side of Grays Harbor Entrance, was sampled for comparison with Half Moon Bay. Depth surveys conducted prior to traviling showed that the North Entrance site was characterized by irregular bottom topography, including 4 - to 5 - ft high sand waves. These conditions restricted sampling in this area. 


\subsection{METHODS}

The field effort for the 1991 Grays Harbor crab distribution survey was completed between June 18 and 21, 1991, with the chartered vessel FV Karelia from Westport, Washington. Each sampling effort (bottom trawl, sediment sample, or hydrographic cast) was assigned a unique station number starting with the number 301 for work in June 1991. Crab distribution and density were estimated from trawls with a 3-m, plumb-staff beam trawl. A minimum of four bottom trawls were planned at each of the five sites. To the best of the vessel's ability, trawls were oriented parallel to bottom depth contours. For proper operation of the trawl net, it was necessary to orient the direction of the trawls into the bottom currents, as estimated from the tidal phase. The trawls were conducted for 10 min after the net contacted the bottom with a scope of four to one and a vessel speed of 2 to 4 knots. These sampling procedures were similar to trawls conducted for the 1990 crab distribution survey (Higgins and Pearson 1991) and the spring 1985 survey (Pearson et al. 1987). A particular trawl was considered unacceptable if benthic organisms were absent (e.g., the catch was limited to pelagic organisms), or if the net was twisted or open upon retrieval.

For the two offshore sites, the Southwest Ocean Disposal Site and the reference area to the north, a statistical review of 1990 catch data indicated that four trawls at each site would provide adequate statistical power for quantitative comparison of YoY crab densities. In 1991, statistical power was estimated in the field using preliminary results of the first four trawls to determine if the sampling effort was sufficient to detect a significant difference between sites. Statistical power, based on the $Z$ statistic at $\alpha=0.05$, was calculated using the observed differences in the mean crab density from the two sites (Snedecor and Cochran 1980).

Trawls were sorted only for Dungeness crabs plus major epifaunal taxa. Dungeness crabs were sorted into juveniles (carapace width $\leq 50 \mathrm{~mm}$ ) and adults (carapace width $>50 \mathrm{~mm}$ ). The total catch of juvenile Dungeness crab was counted and weighed (wet weight). If the number of juvenile Dungeness crab in a trawl exceeded 100, a subsample was weighed and counted, and the total number of juveniles estimated from the subsample weight and the total juvenile 
catch weight. Carapace width (CW) measurements were made on a total of twenty juveniles from each trawl. Individual adult Dungeness crab were weighed and counted, and the carapace width, shell hardness, gender, and presence (or absence) of eggs were recorded.

Catch characteristics recorded were total weight of the catch, nature and weight of debris, and total wet weight of organisms from each major epifaunal taxon. The major epifaunal taxa were pooled into the following categories: other crustaceans (e.g., shrimp and hermit crabs), echinoderms (e.g., sand dollars and sea stars), mollusks (e.g., snails and clams), flat fish, round fish, and other biota (e.g., jellyfish). Some trawls contained extraordinary volumes of debris that could have caused significant inaccuracies in counts of small crab if an attempt had been made to sort the entire catch. The larger components from these trawls (e.g., flat fish, large round fish, large debris, and adult crabs) were removed from the whole catch and counted. The remainder of the catch was spread out on a flat surface and split into a manageable fraction (e.g., 1/2 or 1/4). The contents of one split fraction was carefully sorted for smaller animals (e.g., juvenile crab or fish, crab larvae, and shrimp). Data from the split fraction were then adjusted with an appropriate multiplier to estimate the full trawl catch.

The vessel position was located using a LORAN system and recorded for each sampling event. The record of sampling activity is provided in Appendix A. The LORAN positions recorded from the FV Karelia were calibrated by determining the coordinates at five fixed buoys in the study area (R"2", RW"GH", G"13", G"5", and QR"2") (Figure 1.2). The deviation of LORAN positions from coordinates on the Grays Harbor oceanographic chart (\#18502) was consistent (mean deviation $=00.37^{\prime} \mathrm{N}$ latitude and $09.51^{\prime} \mathrm{W}$ longitude), and coordinates in this report were adjusted to accurate readings using a mean correction factor.

At each site on each day that sampling occurred at the site, one hydrographic cast was made to obtain depth profile of temperature and conductivity using an Interocean (a) probe. Measurements were made at $1-m$ intervals in the top $5 \mathrm{~m}$ of the water column and at 5-m intervals thereafter.

(a) InterOcean Systems, 3540 Arrow Court, San Diego, CA 92123. 
The hydrographic probe and a weighted line were used to confirm the accuracy of the vessel's depth sounder. Water depths associated with sampling events were recorded from the ship's depth sounder and were not corrected for tidal height.

Surface sediment samples for grain-size analysis were collected from the three nearshore sites (South Beach, Half Moon Bay, and North Entrance) using a modified Van Veen grab $\left(0.1 \mathrm{~m}^{2}\right)$. No surface sediment samples were taken from the two offshore sites. The upper $2 \mathrm{~cm}$ of sediment were taken from the grab contents and stored in plastic bags. At the South Beach site, ten sediment samples were collected, one from each corner of the site, one mid-way along each side of the site, one in the center of the site, and another chosen arbitrarily at the discretion of the Project Leader. At the Half Moon Bay site, five sediment samples were collected, one from each corner of the site and one from the center of the site. At the North Entrance site, two seoiment samples were collected, one from the midpoint of each trawl. Grain-size analysis was conducted by Soil Technology (a) to determine percent composition of gravel, sand, and silt and clay on dry sediment samples using Method D-422 (ASTM 1972).

Although our preliminary letter report to USACE discussed juveniles and adults (based on the $50-\mathrm{mm} \mathrm{CH}$ distinction), this classification proved inadequate. The Site Monitoring Plan (Pearson 1987) focuses on YoY age class densities of Dungeness crab for the Tier 1 evaluation of the Southwest Ocean Disposal Site prior to disposal of dredged materials. However, because $1^{+}$age class Dungeness crab can range from 30 to $85 \mathrm{~mm} \mathrm{CW}$ in early summer (Armstrong et al. 1989), $1^{+}$age class Dungeness crabs may fall into both the juvenile and the adult classes if the distinction is based exclusively on the $50-\mathrm{mm} \mathrm{CW}$ size. Moreover, relatively high numbers of megalopae were found at several sites, and in a two-category classification scheme, these would be grouped with the YOY. Because of the size class distribution observed, Dungeness crab were categorized into four age classes (i.e., megalopal larvae, $\mathrm{O}^{+}$or YOY, $\mathrm{I}^{+}$, and adults) rather than just two categories [i.e., juvenile ( $\mathrm{CW} \leq 50 \mathrm{~mm}$ ) and adult $(\mathrm{CW}>50 \mathrm{~mm})$ ] as specified in the Work Plan. Field records were

(a) Soil Technology, 7855 N.E. Day Road West, Bainbridge Island, WA 98110 
compiled in a manner that allows for estimation of crab densities using a four-category system.

For this report, crab were assigned to an age class based on their body shape as well as carapace width. Although megalopal larvae of Dungeness crab have a shell, their body shape is not that of an adult crab. The ranges of carapace width for different age classes are from Armstrong et al. (1989). Dungeness crab in the YoY or $0^{+}$age class have the shape of adult crabs with a $\mathrm{CW}$ of only 6 to $29 \mathrm{~mm}$. Crab in the $1^{+}$age class have a CW of 30 to $85 \mathrm{~mm}$. All crab with $\mathrm{CW}>85 \mathrm{~mm}$ were classified as adult crab.

Crab densities from the Southwest Ocean Disposal Site and the north reference area were compared using the nonparametric Mann-Whitney test for equivalence of population location parameters (i.e., median) (Daniel 1978). This test is based on ranked data, thus eliminating the potential bias of extremely large and small trawl catches. Past data (Pearson et al. 1987; Higgins and Pearson 1991) have indicated that crab are not randomly spaced within either site but instead are clumped in a patchy distribution. Parametric analyses, such as the t-test and analysis of variance, on raw catch data involve specific assumptions about the underlying distribution that cannot be verified with the small number of trawls at each site $(n=6)$. five sites were compared using the nonparametric Kruskal-Wallis one-way analysis of variance by ranks (Daniel 1978). Trawl catches were converted to relative density of crab (or other biological categories) as crab per hectare by dividing the number of crab by the area swept. The area swept was calculated from the distance towed and the effective fishing width $(2.3 \mathrm{~m})$ previously determined for the net design (Armstrong et al. 1985). Because trawl data were not corrected for net efficiency, all densities mentioned in this report are relative rather than absolute. Catches are reported as mean density (\#/ha) for an age class of crab followed by the standard deviation (s) in parentheses. 


\subsection{RESULTS AND DISCUSSION}

General observations of the trawl catches, Dungeness crab densities at each site, crab distribution with depth, and non-crab macroepifauna are presented and discussed in Section 3.1. Results of surface sediment sample analyses are discussed in Section 3.2. Section 3.3 describes the hydrographic profiles.

\subsection{TRAWL CATCHES}

Twenty successful trawls were completed: 1) five each at the two offshore sites, 2) four each at South Beach and Half Moon Bay, and 3) two at the North Entrance site. Figure 3.1 shows the location of all trawls except the 4 trawls in Half Moon Bay, which were tightly spaced within the bay. Even though an evaluation of initial catch results from the offshore sites indicated that four trawls would have been sufficient to determine a significant difference in densities of YoY Dungeness crab, one additional trawl was taken at each of these sites to provide a greater sample size to strengthen statistical analyses. As discussed in Section 1.3, the bathymetry of the channel bottom over a large proportion of the North Entrance site was not amenable for trawl sampling. Nevertheless, two trawls were completed in areas between the 28 - and $34-\mathrm{ft}$ contours where the bottom was level enough to allow trawling.

The trawl catches of Dungeness crab are summarized in Table 3.1. Data from size and weight measurements on Dungeness crab are in Appendix $B$. In general, densities of Dungeness 1 at each site were highly variable, with the standard deviation approximating the mean for each age class at a given site. This substantiates the conclusion that crab distribution is patchy within the areas sampled. Adult crab constituted a minor portion $(<0.5 \%)$ of trawl catches at the three sites outside Grays Harbor. The two sites within Grays Harbor, i.e., the Half Moon Bay and North Entrance sites, had higher percentages of adult crab, $4.6 \%$ and $23.3 \%$ of the total crab catch, respectively. In a comparison of all five sites using the Kruskal-Wallis 


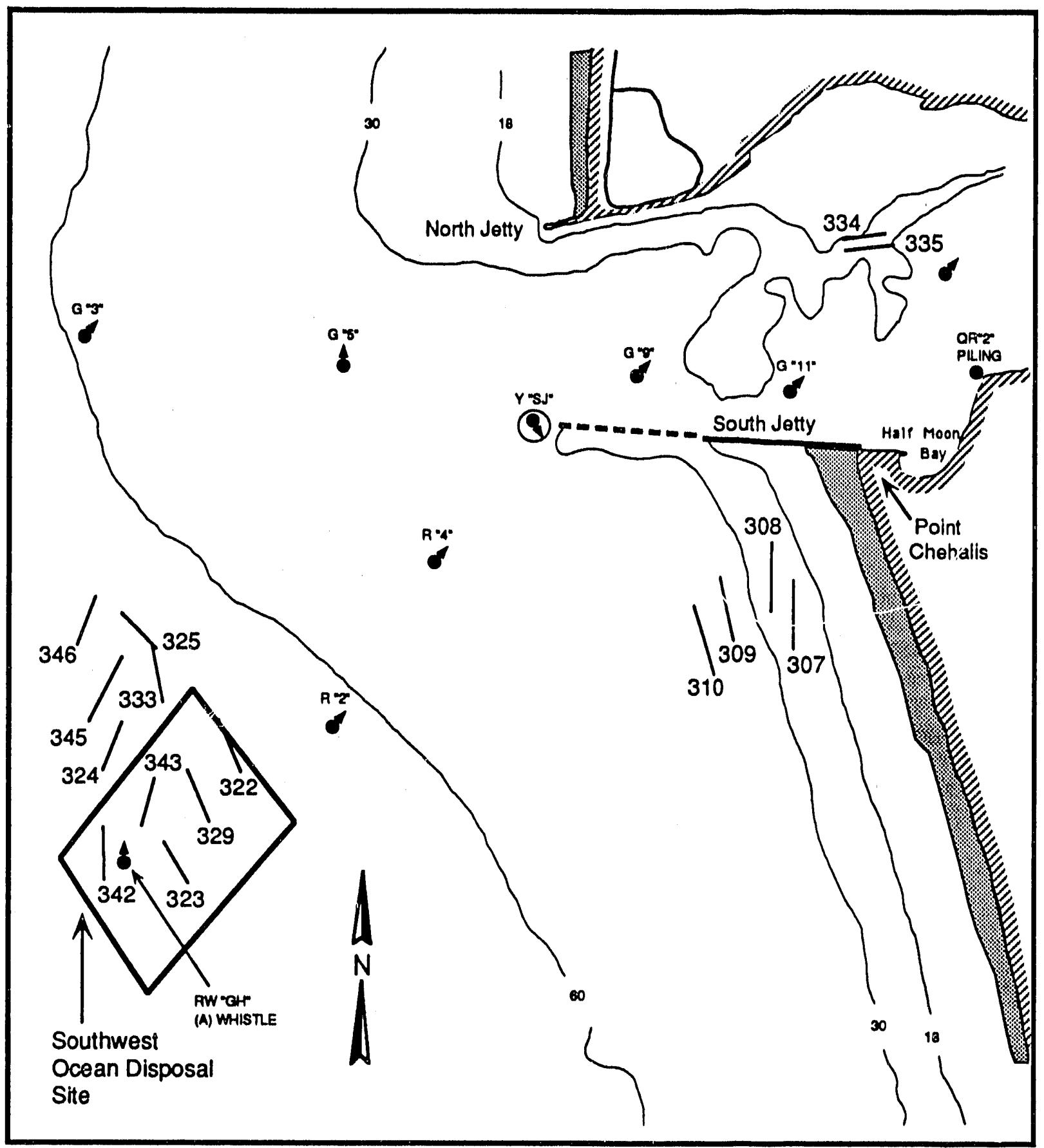

FIGURE 3.1. Locations for the Trawling Stations in June 1991 (Half Moon Bay Trawls not shown; depth contours are in feet.) 


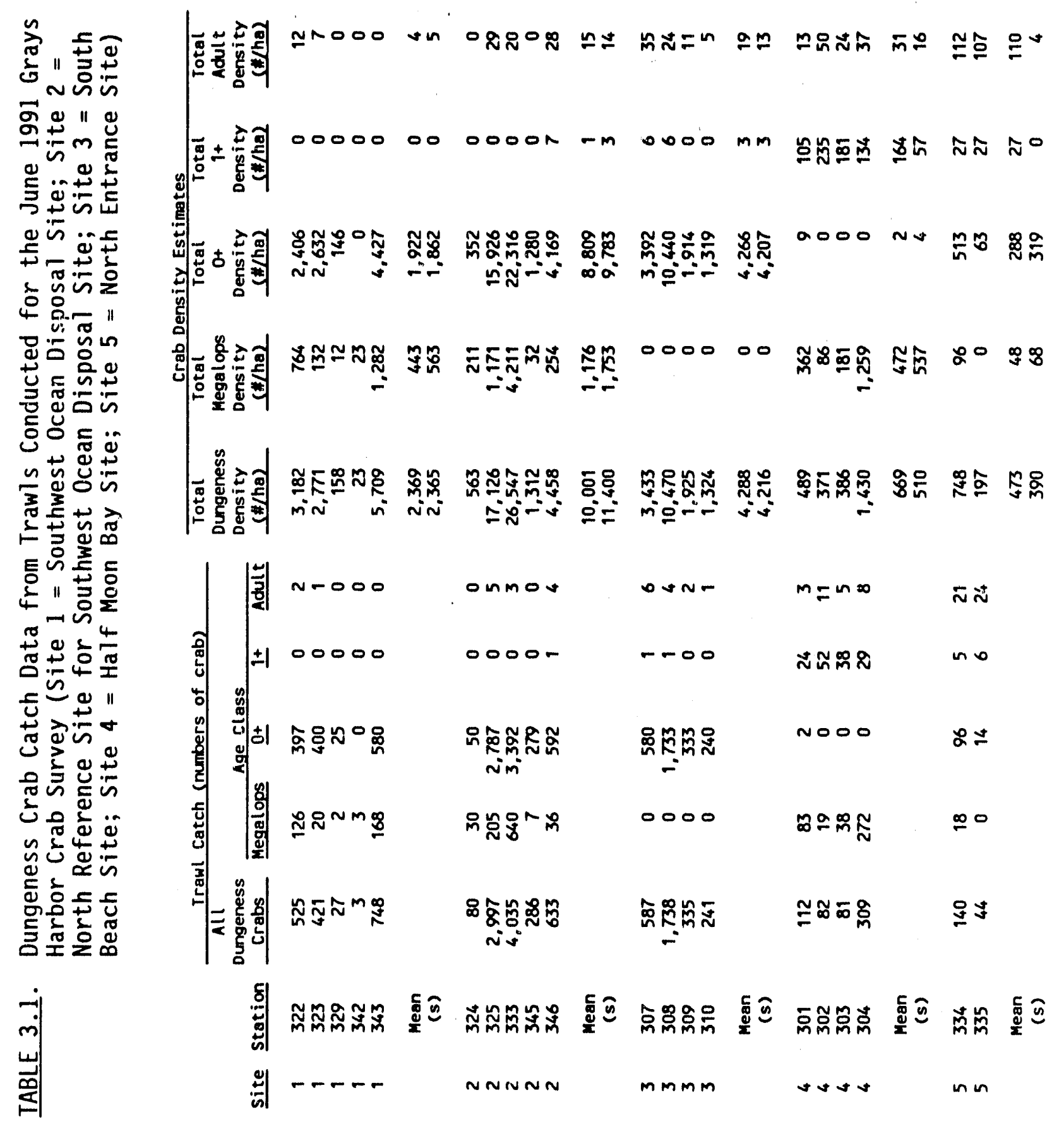


analysis of variance on ranks, the density of adult crab was found to be significantly different $(p<0.03)$, with adult crab density being low at the Southwest Ocean Disposal Site and high at the North Entrance site.

Crab catches at most sites sampled in June 1991 were dominated by YoY Dungeness crab. Of the total Dungeness crab catch, YoY crab accounted for $81 \%$ at the Southwest Ocean Disposal Site, $88 \%$ at the reference area to the north of the disposal site, $99 \%$ at South Beach, $<1 \%$ at Half Moon Bay, and $61 \%$ at the North Entrance site. When these data are pooled by area and depth, a maximum YOY density is found at the offshore sites, which were between 81 and $120 \mathrm{ft}$ depth (Figure 3.2). This peak, however, is strongly influenced by two trawls from the shallower portions of the north reference site (Table 3.1), a finding similar to that of previous surveys (Pearson et al. 1987). In general, the density of YOY Dungeness crab was higher outside Grays Harbor than inside the harbor entrance (Half Moon Bay and North Entrance sites). However, sites in the harbor entrance had a better representation of $1^{+}$and adult age class Dungeness crab than sites outside Grays Harbor.

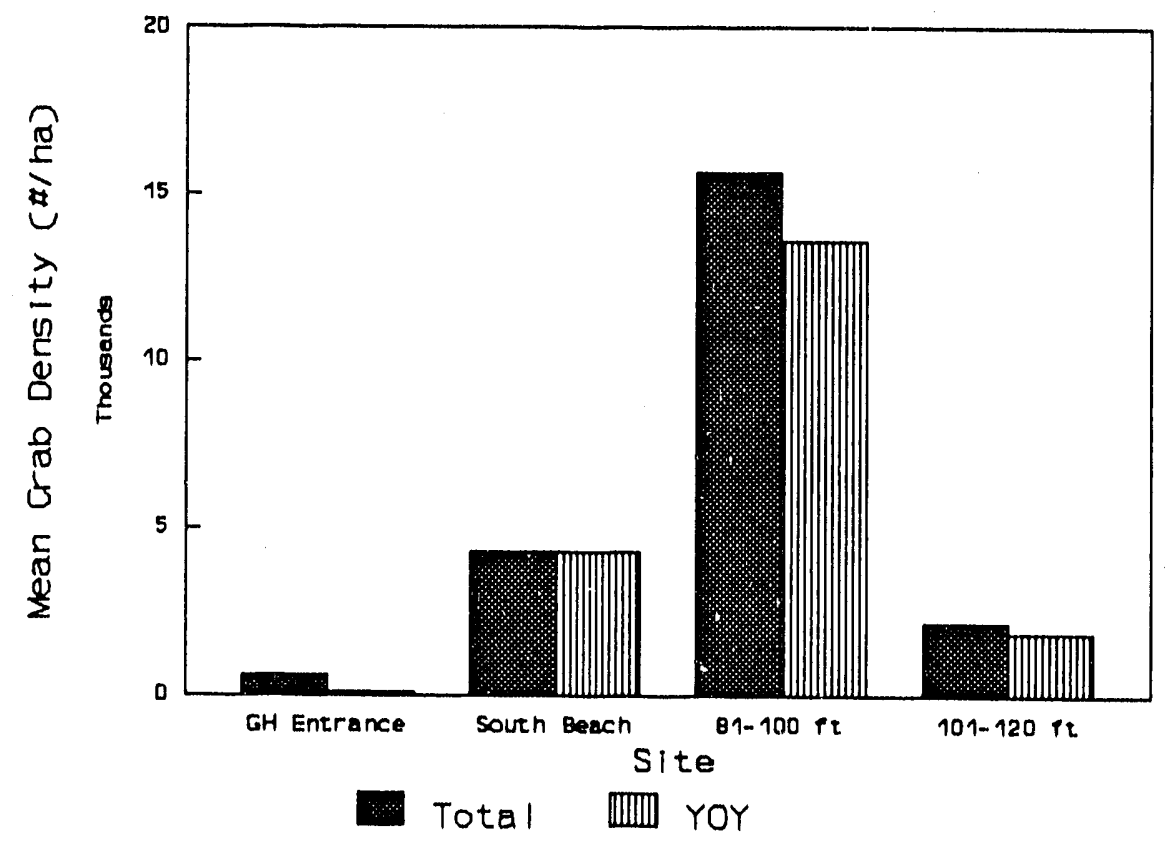

FIGURE 3.2. Mean Density of Dungeness Crab (Total Crab Catch and YoY Only) from Nearshore (Grays Harbor Entrance and South Beach) and Offshore (81- to 120-ft Depth) Areas Sampled in June 1991 
To analyze the spring distribution of YoY Dungeness crab with depth off Grays Harbor in June, data are available from surveys in 1985 (Pearson et al. 1987), 1990 (Higgins and Pearson 1991), and 1991. Because the sampling effort at different depths varied between years, data from each year were pooled into depth ranges representing sites closer to shore $(<80-\mathrm{ft}$ depth) and the depth range at the Southwest Ocean Disposal Site (between 80 - and 140-ft depth). To eliminate the effect of annual recruitment success of YoY crab, data were normalized to the maximum YOY density for the year (i.e., YOY density divided by maximum YOY density for the year). No clear trends emerge from this analysis (Figure 3.3). Even with norma?ized data, dramatic variability in YoY density with depth is evident between years. Much of this variability can be attributed to a few trawls with exceptionally high catches of yoy crab, particularly in 1985 and 1991.

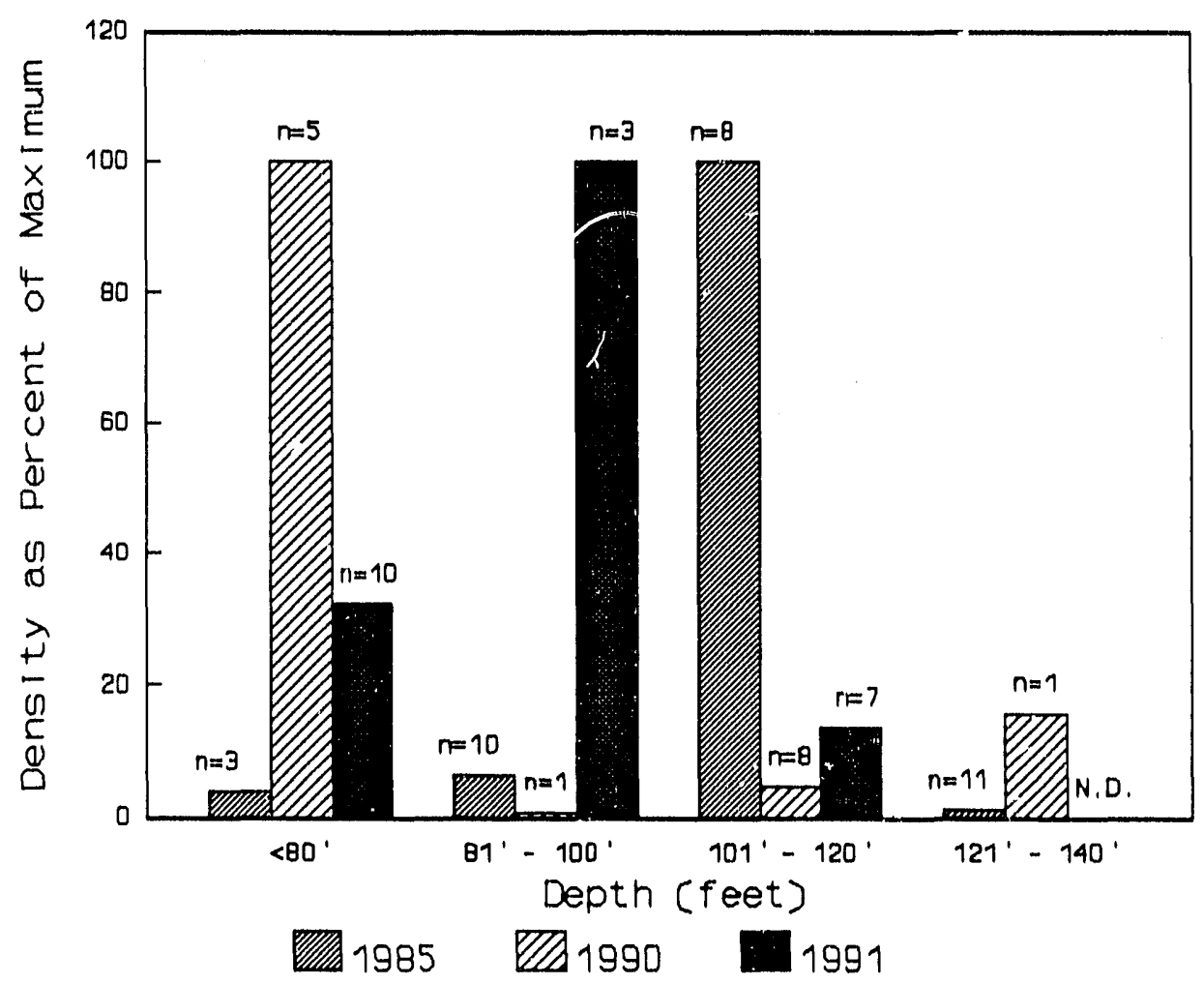

FIGURE 3.3. Density of YOY Dungeness Crab By Depth from June 1985, 1990, and 1991 Surveys at Grays Harbor, Washington, as Percent of Maximum Catch for the Year ( $n=$ sample number; N.D. = no data available) 
Megalopal larvae of Dungeness crab were sighted in the water column at Half Moon Bay on two days during field operations. The megalopae were actively swimming toward the east, i.e., in an onshore direction, and they were also being carried in the same direction by the current. Their distribution appeared to be patchy. Armstrong et al. (1989, page 45) report that megalopae were common in neuston of Grays Harbor in 1983 and 1984 in small convergence zones that occur along parallel drift lines during flood tide. The 1991 observations of megalopae in Half Moon Bay may correspond to this phenomenon.

Because a beam trawl is open and fishing during deployment and retrieval, megalopae from the water column can be caught and incorporated into a trawl sample. Thus, megalopae in the trawl catches could have been taken from the water column rather than the bottom. Although accurate counts of megalopae were made from each trawl catch in June 1991, it is not possible to estimate the proportions of megalopae collected from the bottom vs. the water column. Large numbers of megalopae were found in several trawls, yet megalopae were a major component (>20\%) of the total Dungeness catch only at Half Moon Bay (Table 3.1).

The types of macroepifauna collected in trawls, excluding Dungeness crab, were similar at all sites sampled. Catches were dominated by English sole, crangon shrimp, an unidentified juvenile round fish, and an assortment of other round fish (Appendix $C$ ). The only crab taxon found other than Dungeness crab was hermit crabs. The total density of non-Dungeness crab macroepifauna (sum of major epifaunal taxa in Table C.1) was significantly different between sites, based on Kruskal-Wallis analysis of variance on ranked data $(p=0.01)$. In general, the density of macroepifauna differed between offshore and nearshore sites, with offshore sites having higher densities of macroepifauna.

Although the macroepifaunal catch was similar from the two offshore sites, the debris from these two sites was notably different. No significant debris was collected in any of the five trawls completed at the disposal site. However, three of the five trawls completed north of the disposal site contained relatively large amounts of debris. Catches of both juvenile and adult Dungeness crab were higher in the trawls containing debris. The debris in trawls from the reference area north of the disposal site consisted mostly 
of large wood pieces and algae, which may have been concentrated in patches where crab congregated for a protected habitat. Armstrong et a1. (1989) discuss the use by Dungeness crab of shellhash and debris for a protected habitat.

\subsubsection{Southwest Ocean Disposal Site}

Sampling at the Southwest Ocean Disposal Site was conducted on June 20 and 21, 1991. Five successful traw1s were completed (Figure 3.1) within the boundaries of the disposal site. The mean density of Dungeness crab at this site was $2,369 \mathrm{crab} / \mathrm{ha}(\mathrm{s}=2,365)$ (Table 3.1). Dungeness crab in the YOY or $0^{+}$age class constituted $81 \%$ of the total crab catch, and their density was estimated at $1,922 \mathrm{crab} / \mathrm{ha}(\mathrm{s}=1,862)$ (Table 3.1).

\subsubsection{North Reference Area for the Southwest Ocean Disposal Site}

In the area to the north of the Southwest Ocean Disposal Site, high densities of juvenile Dungeness crab were located in the spring 1985 survey (Pearson et al. 1987). In 1991, five successful trawls were completed on June 20 and 21 (Figure 3.1). These trawls were positioned to survey the area where high densities of crab were found previously, as well as adjacent areas north of the disposal site. The mean density of Dungeness crab at this site was $10,001 \mathrm{crab} / \mathrm{ha}(\mathrm{s}=11,400)$ (Table 3.1). The density of YoY or $0^{+}$age class Dungeness crab was estimated at $8,808 \mathrm{crab} / \mathrm{ha}(\mathrm{s}=9,783)$ (Table 3.1), which is $88 \%$ of the total crab catch for this site. Two trawls that traversed the area where juvenile crab density was high in 1985 contained exceptionally high crab numbers in June 1991 as compared to other trawls in this area or at the disposal site. These two trawls produced density estimates of 15,926 and 22,316 YoY Dungeness crab/ha. With the exception of these two trawls, catches of YOY Dungeness crab from the north reference area were similar to those from the disposal site.

\subsubsection{Comparison of YOY Dungeness Crab Catches from Offshore Sites}

The primary focus of monitoring activities and decision-making under the Site Monitoring $\mathrm{Plan}$ is YOY or $\mathrm{O}^{+}$age class Dungeness crab. In June 1991, the mean density of YOY Dungeness crab was $1,922 \mathrm{crab} / \mathrm{ha}$ (median $=2,406$ ) within the Southwest Ocean Disposal Site and $8,808 \mathrm{crab} / \mathrm{ha}$ (median $=4,169$ ) to the north of and outside the disposal site (Table 3.1). The difference between 
these sites was not significant, as indicated by a two-sided Mann-Whitney rank test $(p=0.3)$.

\subsubsection{South Beach Berm Site}

At the South Beach site, the mean density of all Dungeness crab was $4,288 \mathrm{crab} / \mathrm{ha}(\mathrm{s}=4,216)$ and that of YOY Dungeness crab was $4,266 \mathrm{crab} / \mathrm{ha}$ $(s=4,207)$ (Table 3.1). The density of Dungeness crab (total, YoY, or adults) at South Beach was not significantly different (using Kruskal-Wallis analysis on ranks) from that at the two offshore sites (the Southwest Ocean Disposal Site and the reference area to the north). As noted in Section 3.1, the density of macroepifauna at the South Beach site was not different from that at the two other nearshore sites but was lower than at the two offshore sites.

\subsubsection{Half Moon Bay Berm Site}

The catch of Dungeness crab at Half Moon Bay was characterized by low numbers of YOY crab and relatively high numbers of megalopae, adult, and $1^{+}$ age class crab. Only two YoY Dungeness crab were found in the four trawls completed in Half Moon Bay (Table 3.1), although megalopae constituted $71 \%$ of the total Dungeness crab catch at this site. In comparison with other sites sampled in June 1991, Half Moon Bay had a high density of $1^{4}$ age class crab $($ mean $=164 \mathrm{crab} / \mathrm{ha}, \mathrm{s}=57$, Table 3.1). The only other site with a significant catch of $1^{+}$age class crab was the Northern Entrance site $($ mean $=27 \mathrm{crab} / \mathrm{ha}, \mathrm{s}=0)$.

In general, the North Entrance site had more $0^{+}$and adult Dungeness crab and fewer megalopae and $1^{+}$Dungeness crab than Half Moon Bay. However, the catches from the two trawls at the North Entrance site were dissimilar. One trawl contained more debris but smaller catches of megalopae and $\mathrm{O}^{+}$age class Dungeness crab than the other. Because only two trawls were completed at this site, statistical comparisons with catches from Half Moon Bay have little validity. Nonetheless, the North Entrance site did have a higher density of adult Dungeness crab than any other site sampled in June 1991. 


\subsection{SEDIMENT GRAB SAMPLES}

Results of grain size analyses are tabulated as percentage retained, dry weight, and presented graphically in Appendix $D$. Duplicate analyses were analyzed on splits from one sample, and the relative percent difference (RPD) for the three size fractions present was $1.6 \%$. Surface sediment samples from the South Beach site were consistently dominated by fine sand ( $>80 \%$ by weight), which implies that the bottom was homogeneous over the entire South Beach site. However, in contrast to the grab samples of surface sediment, some of the trawls contained significant amounts of gravel in the debris. Therefore, the bottom at this site may not be as homogeneous as surface sediment samples indicate. Gravel probably occurs in bands or patches at this site. The highest number and density of juvenile Dungeness crabs were found in a trawl that had a significant load of gravel debris, which implies that relatively high densities of small crabs may aggregate in patches of gravel at this site.

Surface sediments at Half Moon Bay were also predominantly fine sand at all stations. On the north side of the entrance to Grays Harbor, surface sediments contained more of the coarser materials, including gravel and coarse sand, than the other nearshore sites.

\subsection{HYDROGRAPHIC PROFILES}

Hydrographic profiles are presented in tabular and graphical form in Appendix E. In general, hydrographic profiles taken outside Grays Harbor indicate a well-mixed surface layer approximately $5 \mathrm{~m}$ deep and a trend toward decreased temperature and increased salinity, or greater water density, with depth (Figures E.1 through E.3). The sites within the entrance to Grays Harbor were well mixed over their entire depths (Figure E.4). Strong tidal and coastal currents contribute to significant mixing of the surface waters in the study areas. 


\subsection{CONCLUSIONS}

In June 1991, the mean density of YoY Dungeness crab was $1,922 \mathrm{crab} / \mathrm{ha}$ within the Southwest Ocean Disposal Site and $8,803 \mathrm{crab} / \mathrm{ha}$ in the north reference area, outside the disposal site. The specific criterion for moving from Tier 1 to Tier 2 of the Site Monitoring Plan is that the crab density in June 1991 would have to be 100 times higher within the Southwest Ocean Disposal Site than in the reference area to the north. Because the crab density within the disposal site did not exceed this threshold value, Tier 2 activities are not required. These results indicate that Dungeness crab did not occur at an exceptionally high density in the Southwest Ocean Disposal Site and confirm that the disposal site boundaries remain appropriate.

Trawl catches of Dungeness crab or other major macroepifaunal taxa from two proposed sediment berm sites, South Beach and Half Moon Bay, were similar to catches from other areas sampled for this survey. In general, the density of macroepifauna was higher at offshore sites than at nearshore sites. Adult and $1^{+}$age class Dungeness crab were found at higher densities within Grays Harbor than at the three sites outside Grays Harbor. Megalopae dominated the catch of Dungeness crab at Half Moon Bay. In addition, trawls taken at or near the disposal site contained high numbers of megalopae. However, these larvae may have been collected from the water column, given that megalopae were seen swimming in surface waters at Half Moon Bay on two days between June 18 and 21,1991 . 


\subsection{REFERENCES}

ASTM (American Society for Testing and Materials). 1972. Standard Method for Particle-Size Analysis of Soils. American Society for Testing and Materials, Philadelphia, Pennsylvania.

Armstrong, D. A., D. Gunderson, and J. L. Armstrong. 1985. Juvenile Dungeness Crab Population Dynamics Offshore of the Grays Harbor Estuary, Spring and Summer, 1984. Technical Report to the U.S. Army Corps of Engineers, Seattle District, prepared by A.R.C.S., Seattle, Washington.

Armstrong, D. A., L. Botsford, and G. Jamieson. 1989. Ecology and Population Dynamics of Juvenile Dungeness Crab in Grays Harbor Estuary and Adjacent Nearshore Waters of the Southern Washington Coast. Report to the U.S. Army Corps of Engineers, Seattle District.

Danie1, W. W. 1978. Applied Nonparametric Statistics. Houghton Mifflin Company, Boston, Massachusetts.

Higgins, B. H., and W. H. Pearson. 1991. Dungeness Crab Survey for the Southwest Ocean Disposal Site off Grays Harbor. Washington. June 1990. PNL5045 , prepared for the Seattle District of the U.S. Army Corps of Engineers by Battelle/Marine Research Laboratory, Sequim, Washington.

Pearson, W. H. 1987. Conceptual Plan for the Management and Monitoring of Two Ocean Disposal Sites off Grays Harbor, Washington. PNL-6420, prepared for the Seattle District of the U.S. Army Corps of Engineers by Battelle/Marine Research Laboratory, Sequim, Washington.

Pearson, W. H., D. L. Woodruff, P. Wilkinson, J. S. Young, H. L. McCartney, and D. C. Klopfer. 1987. Data Report for the 1984/1985 Ocean Surveys to Investigate Potential Ocean Disposal Sites off Grays Harbor. Washington. PNL-6280, prepared for the Seattle District of the U.S. Army Corps of Engineers by Battelle/Marine Research Laboratory, Sequim, Washington.

Snedecor, G. W., and W. G. Cochran. 1980. Statistical Methods, 7th ed. The Iowa State University Press, Ames, Iowa.

USACE (U.S. Army Corps of Engineers). 1989. Final Environmental Impact Statement Supplement, Grays Harbor. Washington, Navigation Improvement Project. U.S. Army Corps of Engineers, Seattle, Washington. 


\section{APPENDIX A}

STATION LIST AND TRAWL INFORMATION 


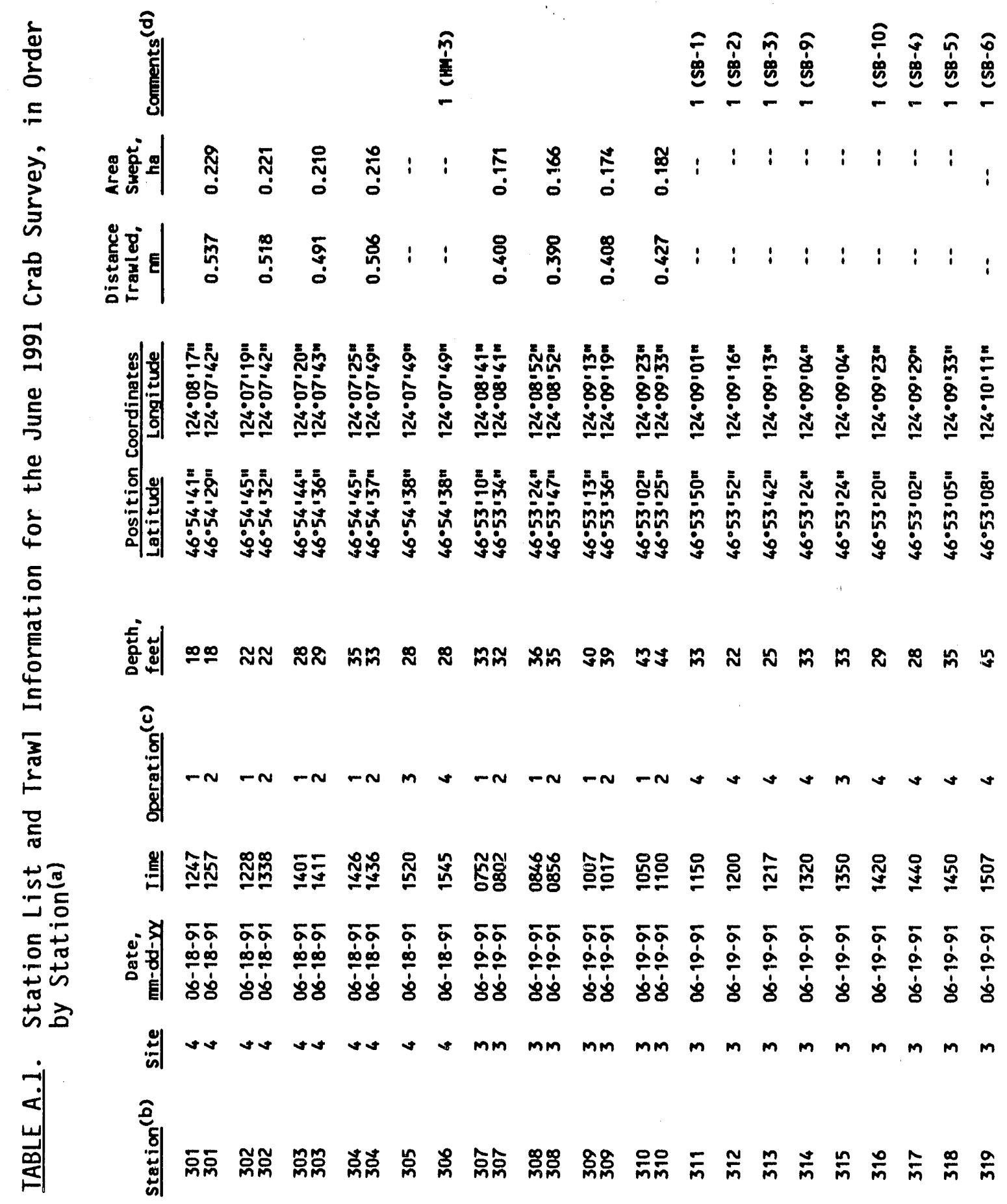

A. 1 


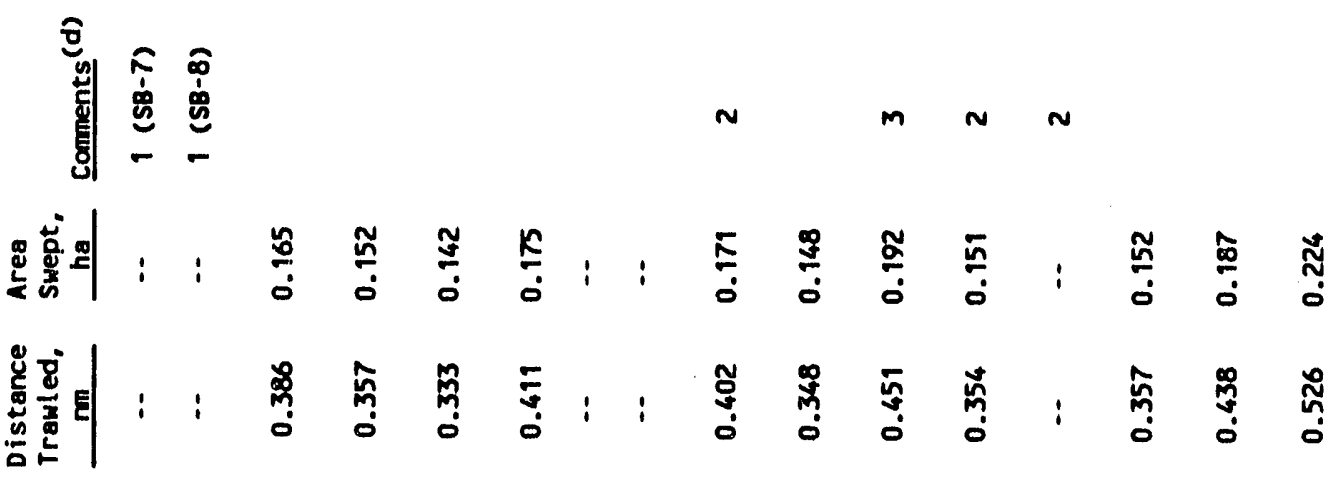

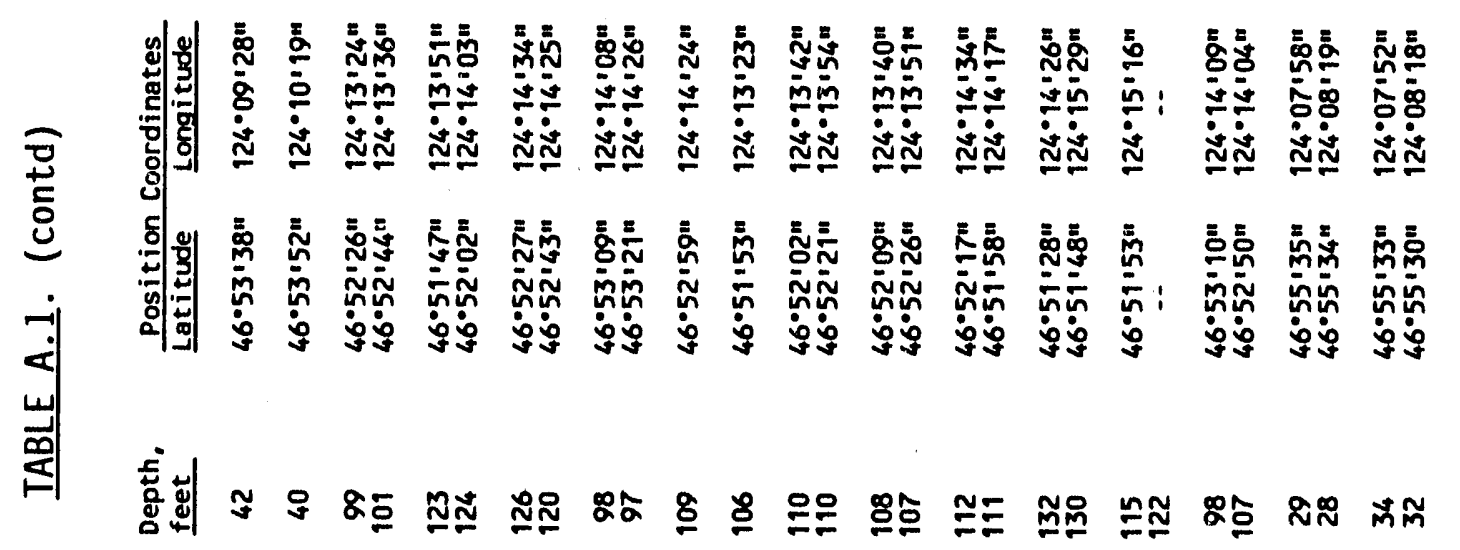
总

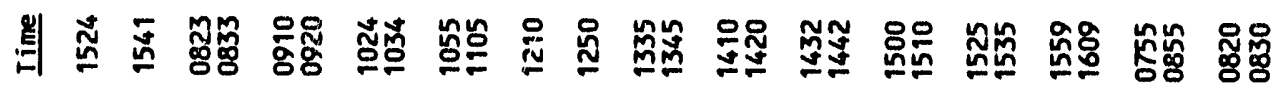

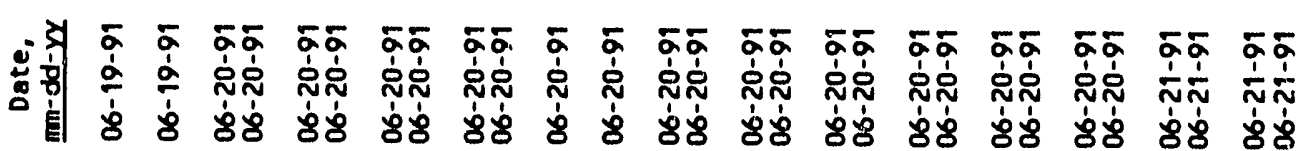

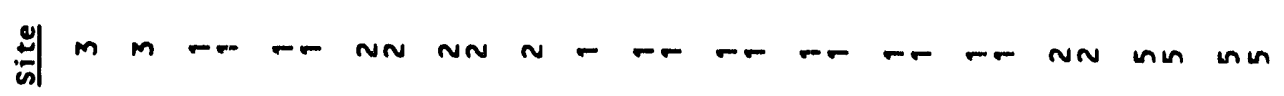

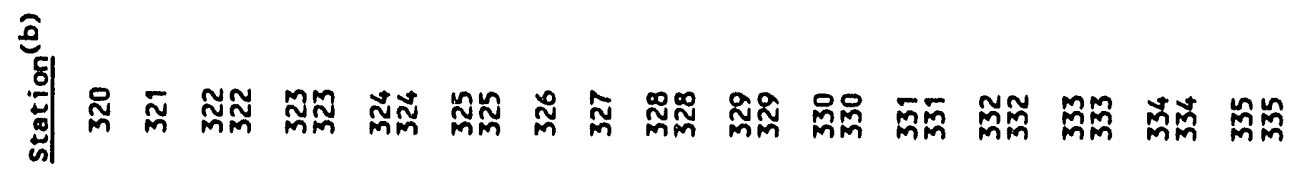

\section{A. 2}




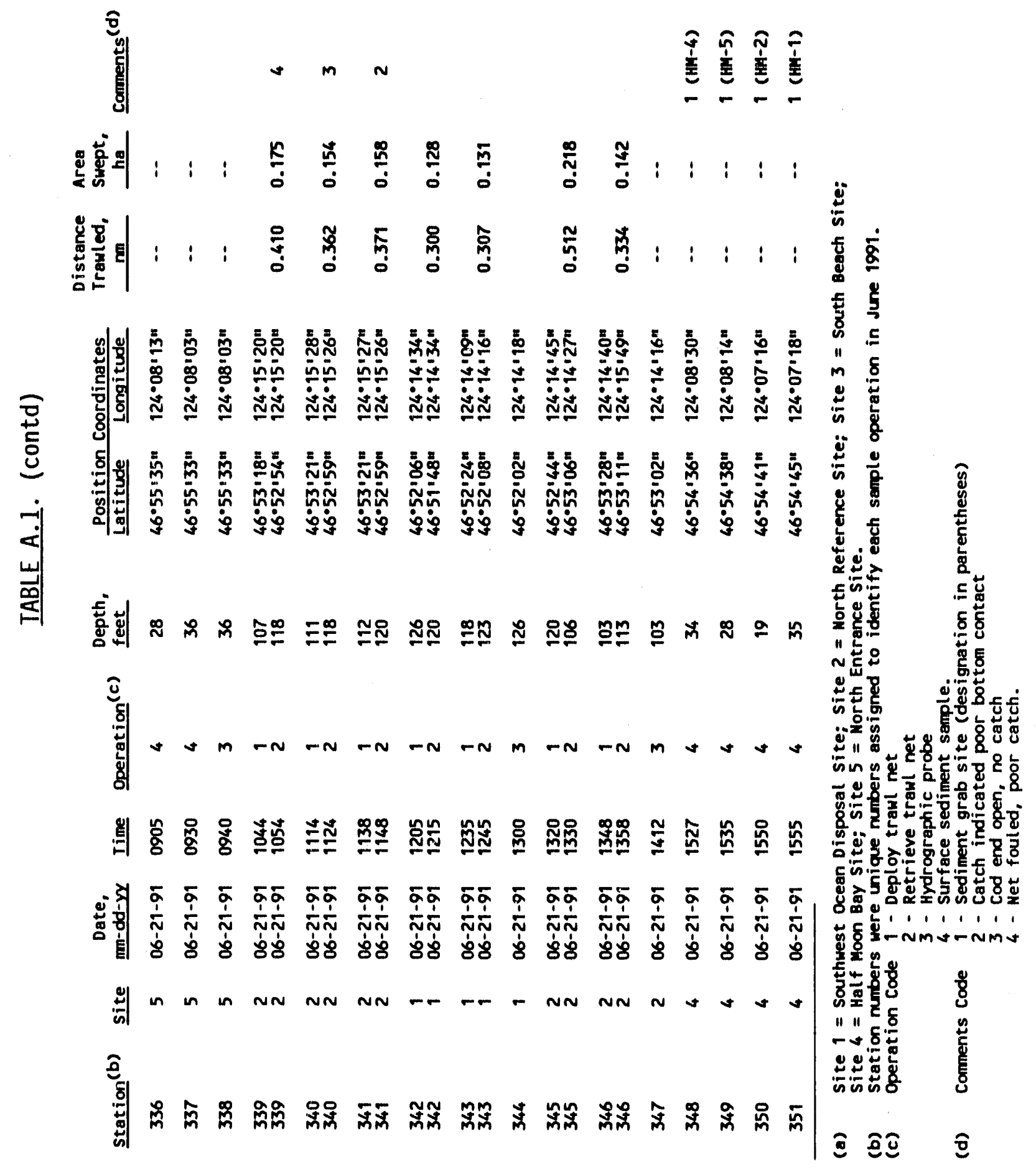


APPENDIX B

DUNGENESS CRAB CATCH DATA 


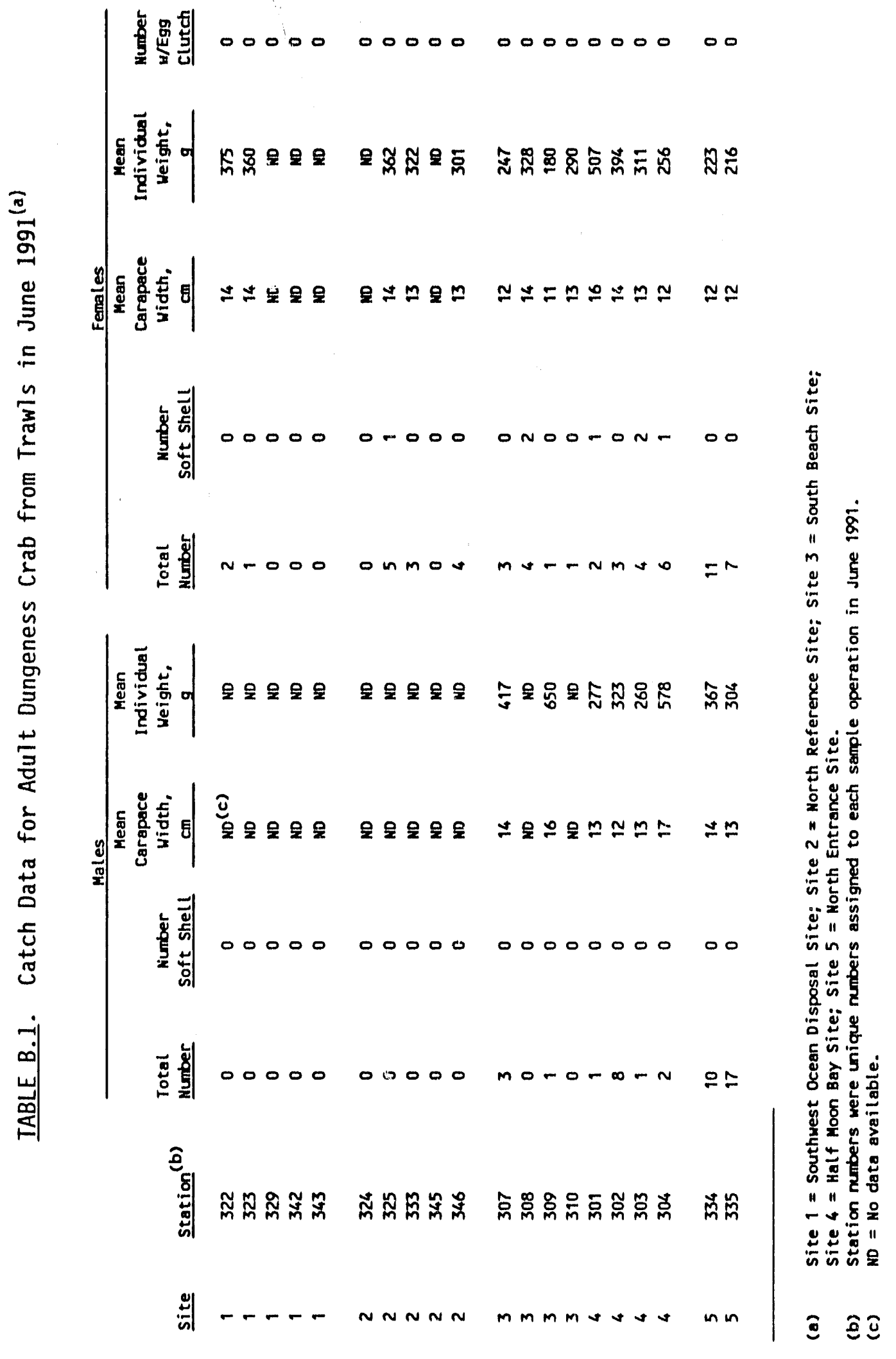

B. 1 
IABLE B.2. Catch Data for $0^{+}$and $1^{+}$Age Class Dungeness Crab from Trawls
in June 1991

\begin{tabular}{|c|c|c|c|c|c|}
\hline \multirow[b]{2}{*}{ Site } & \multirow[b]{2}{*}{$\underline{\text { Station }}^{(\mathrm{b})}$} & \multicolumn{2}{|c|}{$\mathrm{O}^{+}$Age Class } & \multicolumn{2}{|c|}{$1^{+}$Age Class } \\
\hline & & $\begin{array}{l}\text { Total } \\
\text { Number }\end{array}$ & $\begin{array}{l}\text { Mean Carapace } \\
\text { Width. mm }\end{array}$ & $\begin{array}{l}\text { Total } \\
\text { Number }\end{array}$ & $\begin{array}{l}\text { Mean Carapace } \\
\text { Width, mm }\end{array}$ \\
\hline $\begin{array}{l}1 \\
1 \\
1 \\
1 \\
1\end{array}$ & $\begin{array}{l}322 \\
323 \\
329 \\
342 \\
343\end{array}$ & $\begin{array}{r}397 \\
400 \\
25 \\
0 \\
580\end{array}$ & $\begin{array}{r}7.9 \\
7.9 \\
8.1 \\
\text { ND } \\
7.5\end{array}$ & $\begin{array}{l}0 \\
0 \\
0 \\
0 \\
0\end{array}$ & $\begin{array}{l}N D^{(c)} \\
N D \\
N D \\
N D \\
N D\end{array}$ \\
\hline $\begin{array}{l}2 \\
2 \\
2 \\
2 \\
2\end{array}$ & $\begin{array}{l}324 \\
325 \\
333 \\
345 \\
346\end{array}$ & $\begin{array}{r}50 \\
2787 \\
3392 \\
279 \\
592\end{array}$ & $\begin{array}{r}10.0 \\
\text { ND } \\
7.5 \\
7.6 \\
7.9\end{array}$ & $\begin{array}{l}0 \\
0 \\
0 \\
0 \\
1\end{array}$ & $\begin{array}{r}N D \\
N D \\
N D \\
N D \\
\text { ND } \\
31.0\end{array}$ \\
\hline $\begin{array}{l}3 \\
3 \\
3 \\
3\end{array}$ & $\begin{array}{l}307 \\
308 \\
309 \\
310\end{array}$ & $\begin{array}{r}580 \\
1733 \\
333 \\
240\end{array}$ & $\begin{array}{l}9.9 \\
8.3 \\
8.7 \\
7.3\end{array}$ & $\begin{array}{l}1 \\
1 \\
0 \\
0\end{array}$ & $\begin{array}{r}37.0 \\
41.0 \\
\text { ND } \\
\text { ND }\end{array}$ \\
\hline $\begin{array}{l}4 \\
4 \\
4 \\
4\end{array}$ & $\begin{array}{l}301 \\
302 \\
303 \\
304\end{array}$ & $\begin{array}{l}2 \\
0 \\
0 \\
0\end{array}$ & $\begin{array}{r}9.5 \\
\text { ND } \\
\text { ND } \\
\text { ND }\end{array}$ & $\begin{array}{l}24 \\
52 \\
38 \\
29\end{array}$ & $\begin{array}{l}51.2 \\
50.0 \\
51.5 \\
52.5\end{array}$ \\
\hline $\begin{array}{l}5 \\
5\end{array}$ & $\begin{array}{l}334 \\
335\end{array}$ & $\begin{array}{l}96 \\
14\end{array}$ & $\begin{array}{l}7.6 \\
7.4\end{array}$ & $\begin{array}{l}5 \\
6\end{array}$ & $\begin{array}{l}36.6 \\
37.5\end{array}$ \\
\hline
\end{tabular}
(a) $\quad$ Site 1 = Southwest Ocean Disposal Site; Site $2=$ North Reference Site; Site $3=$ South Beach Site; Site $4=\mathrm{Half}$ Moon Bay Site; Site $5=$ North Entrance Site.
(b) Station numbers were unique numbers assigned to each
(c) ND = No data available. 
APPENDIX C

IRAWL CATCH DATA 


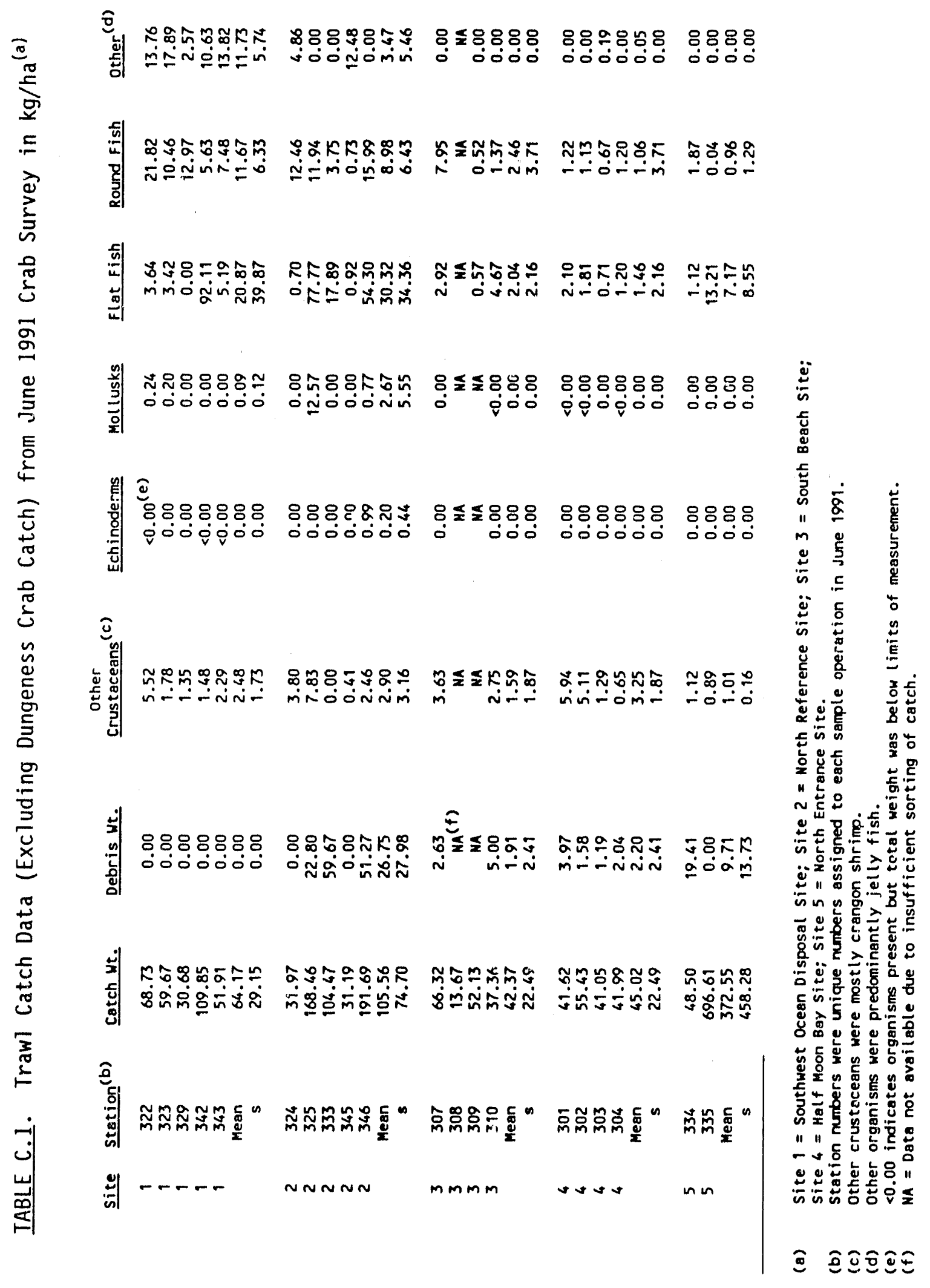

C. 1 
APPENDIX D

SEDIMENT GRAIN SIZE ANALYSIS 

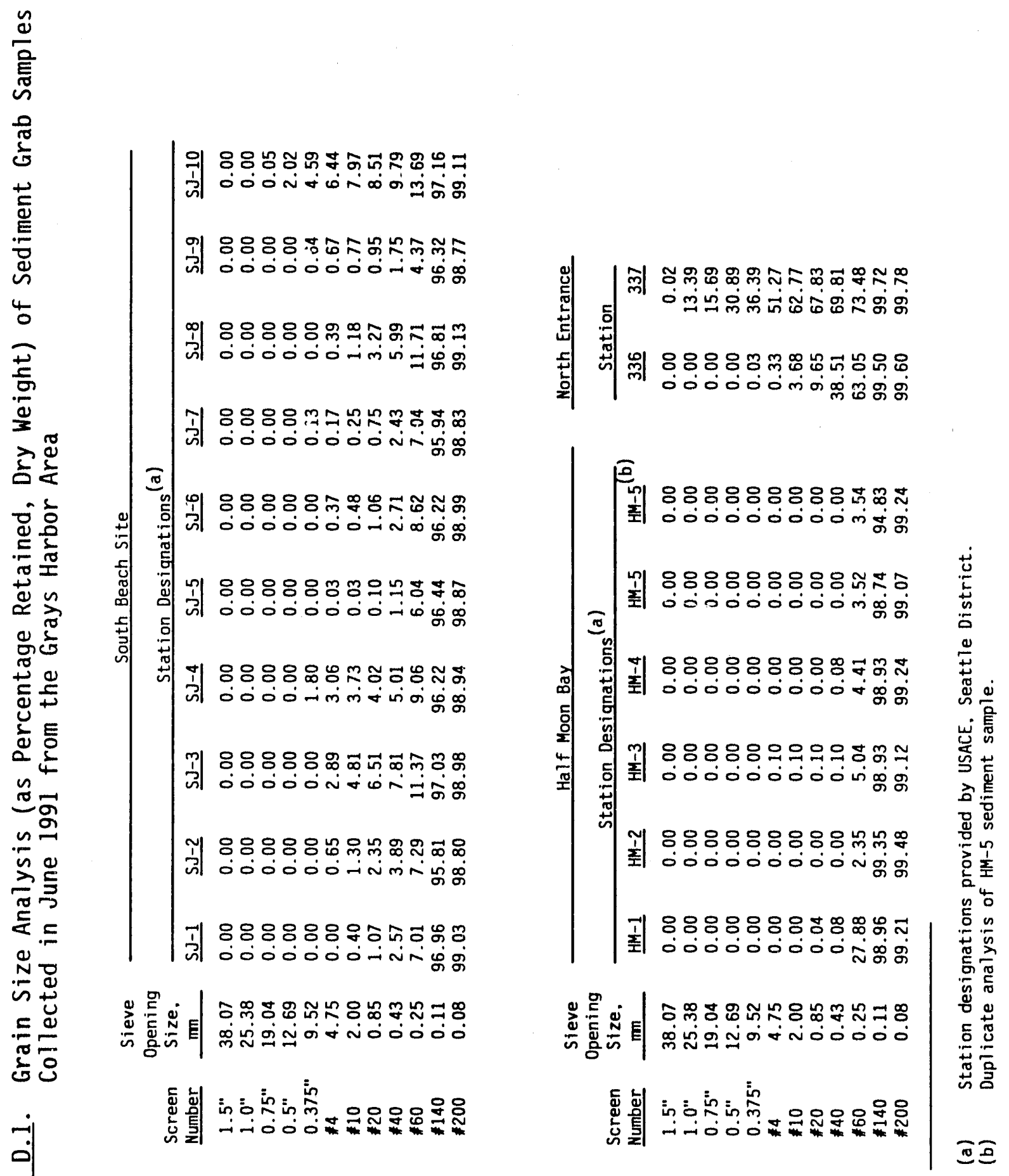

D. 1 


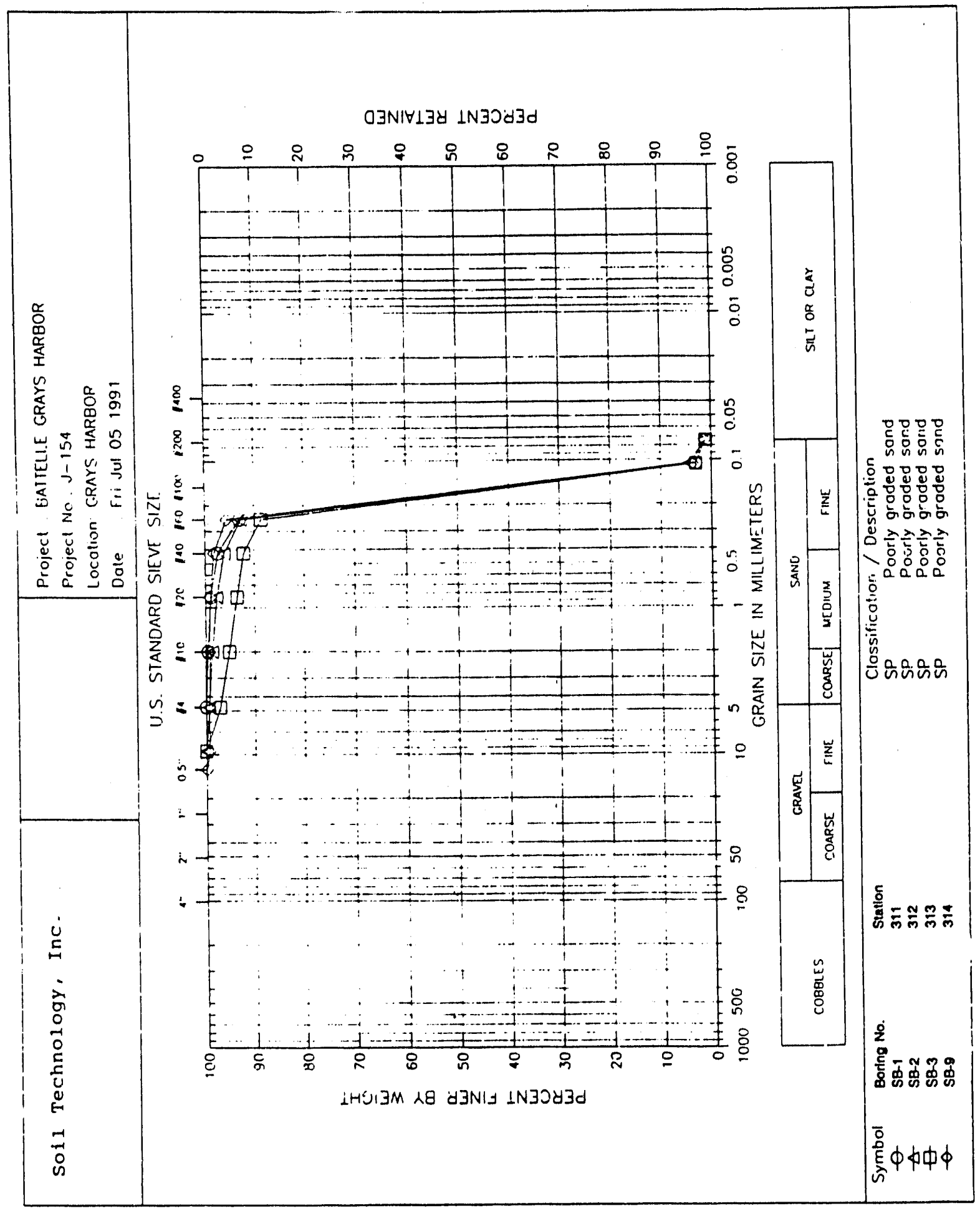

FIGURE D.1. Grain Size Analysis from South Beach (SB) Site, Grays Harbor, Washington, June 1991 


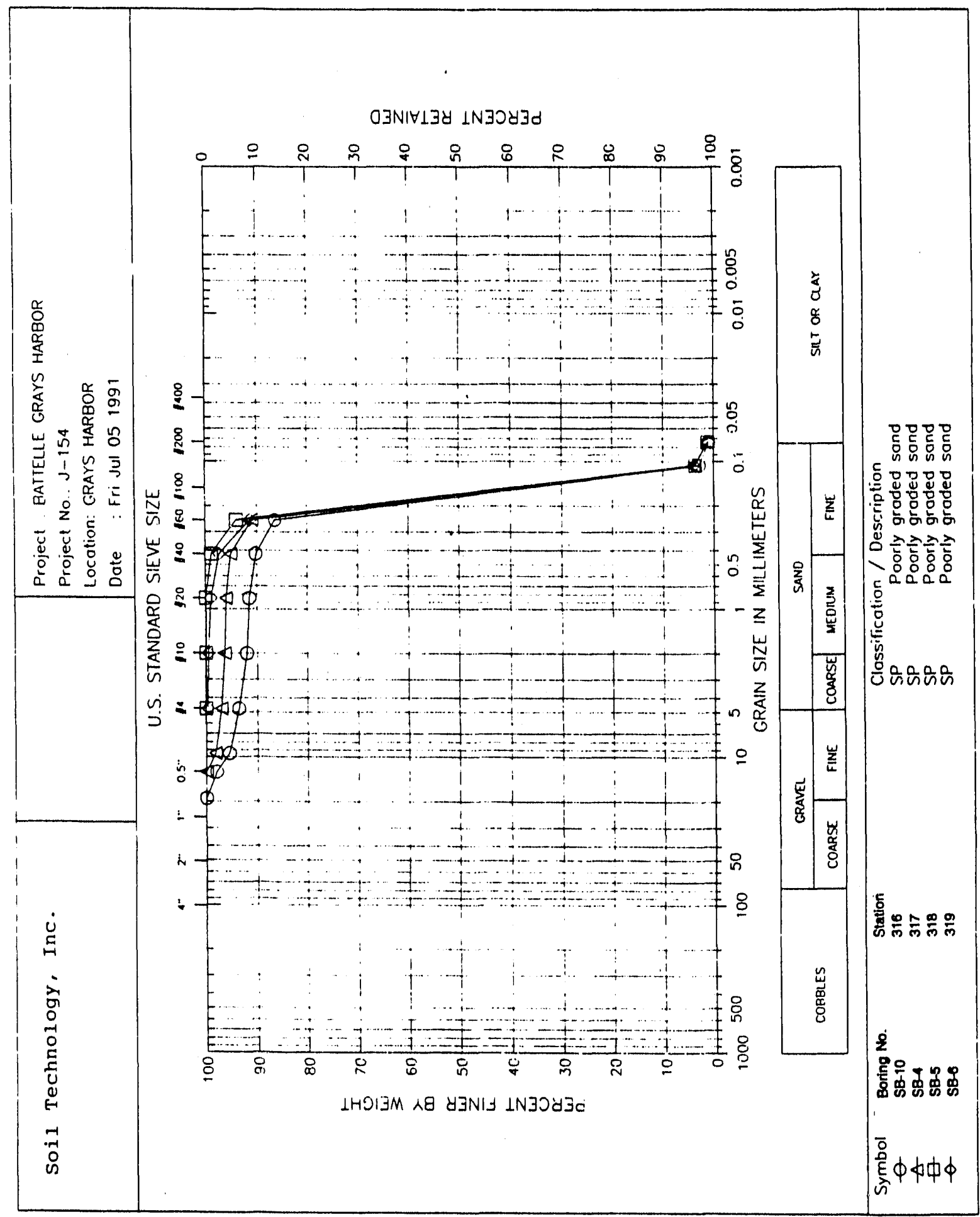

FIGURE D.1. (contd) 


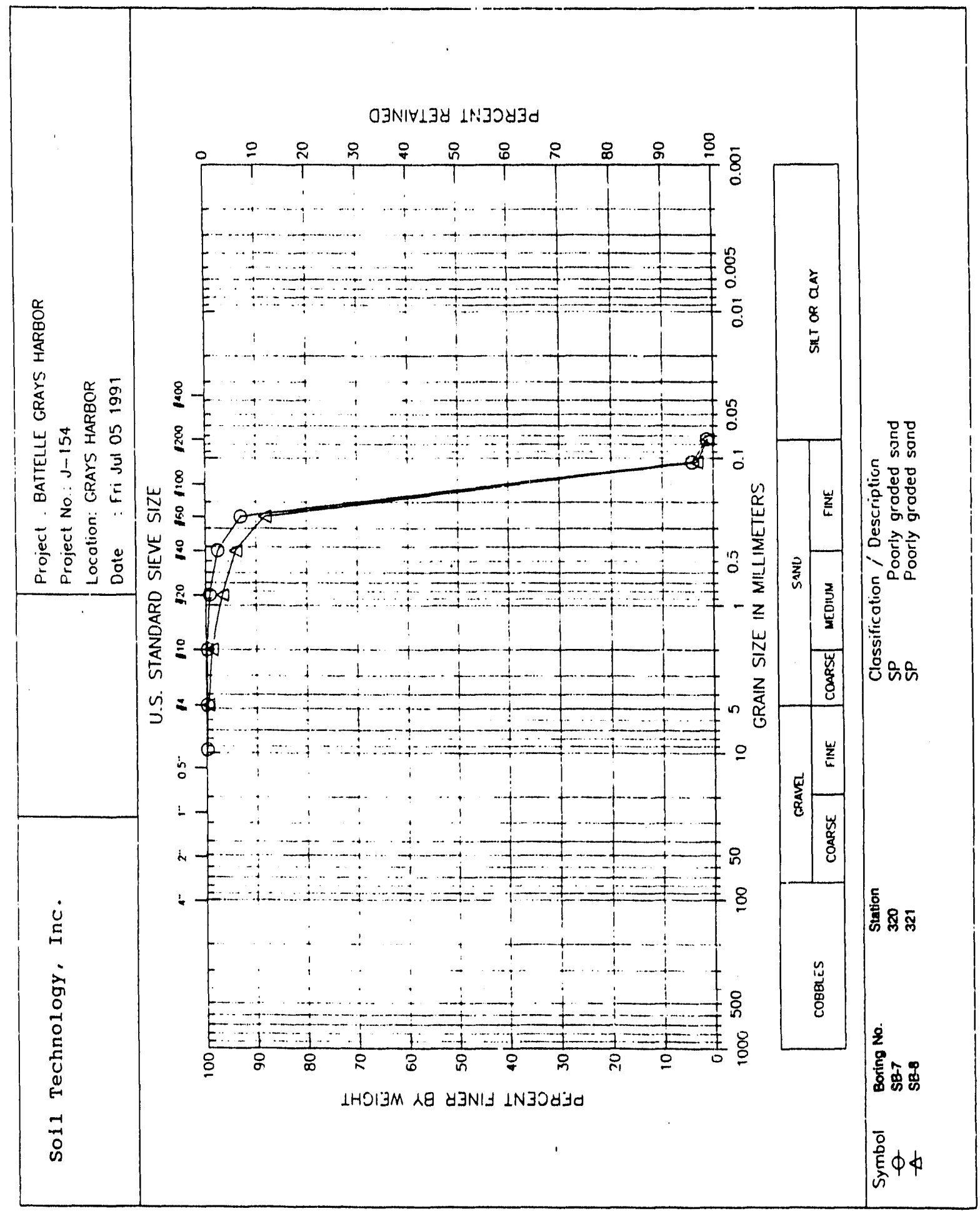

FIGURE 0.1 . (contd) 


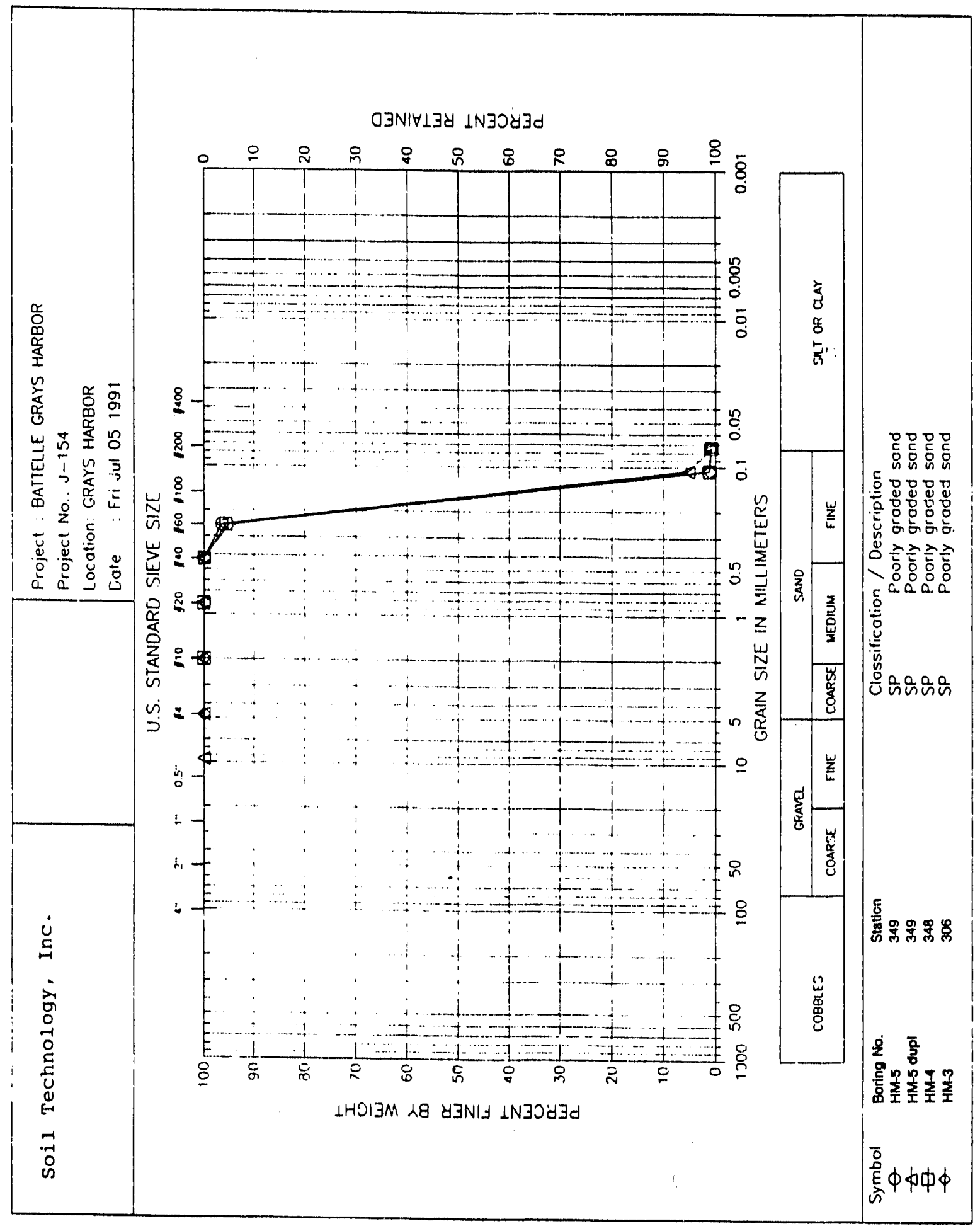

FIGURE D.2. Grain Size Analysis from Half Moon Bay (HM) Site, Grays Harbor, Washington, June 1991 


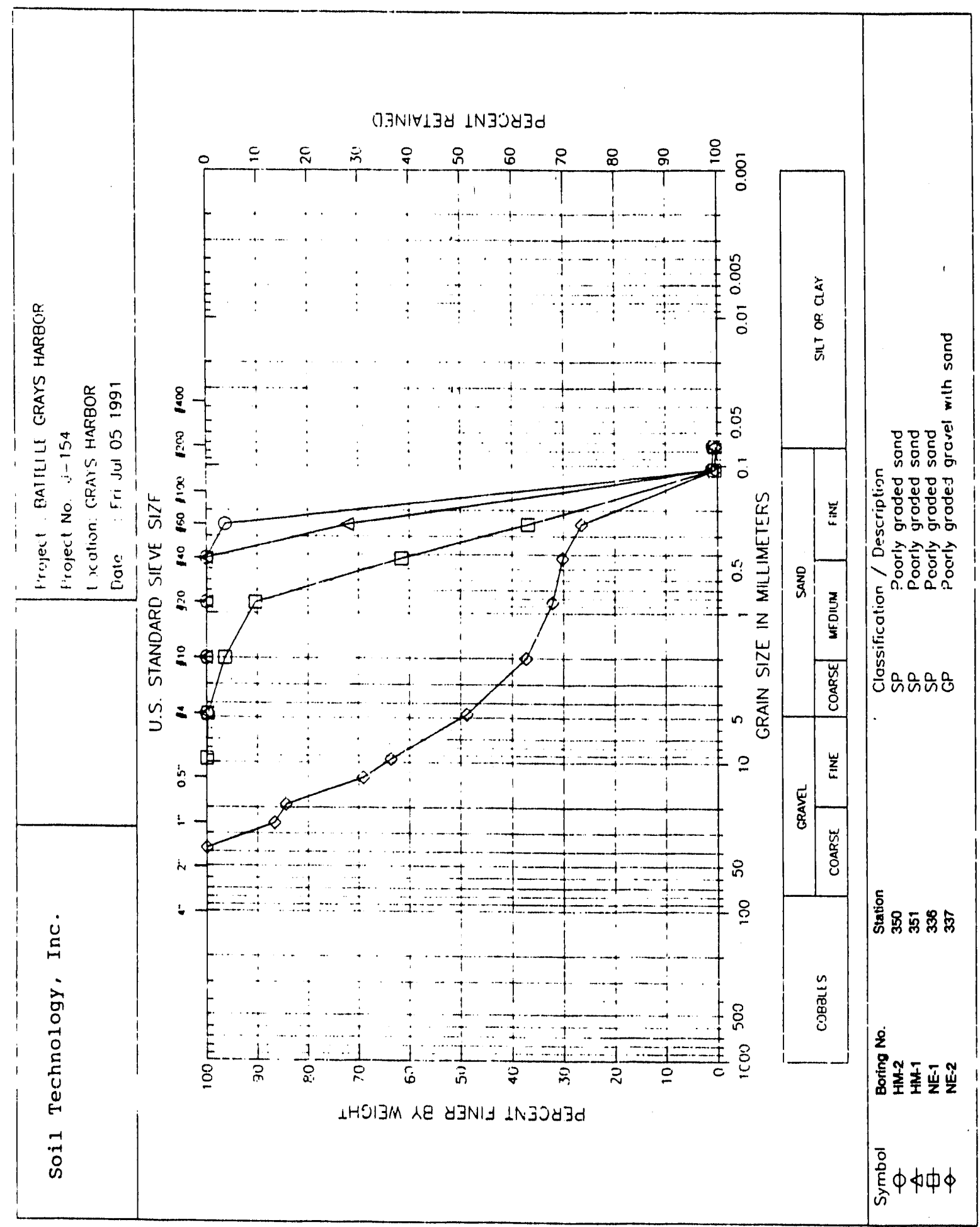

FIGURE D.3. Grain Size Analysis from Half Moon Bay (HM) and North Entrance (NE) Sites, Grays Harbor, Washington, June 1991

D.6 
APPENDIX E

HYDROGRAPHIC PROFILES 
IABLE E.1. Hydrographic Data from Sites Near Grays Harbor, Washington, Collected for the 1991 Dungeness Crab Survey Between June 18 and 21,1991

\begin{tabular}{|c|c|c|c|c|}
\hline Site \# & Date & $\begin{array}{c}\text { Depth, } \\
\text { m }\end{array}$ & $\begin{array}{c}\text { Salinity, } \\
\text { ppt } \\
\end{array}$ & $\frac{\text { Temperature, }}{{ }^{\circ} \mathrm{C}}$ \\
\hline $\begin{array}{l}1 \\
1 \\
1 \\
1 \\
1 \\
1 \\
1 \\
1 \\
1 \\
1 \\
1 \\
1\end{array}$ & $\begin{array}{l}\text { June } 20 \\
\text { June } 20 \\
\text { June } 20 \\
\text { June } 20 \\
\text { June } 20 \\
\text { June } 20 \\
\text { June } 20 \\
\text { June } 20 \\
\text { June } 20 \\
\text { June } 20 \\
\text { June } 20 \\
\text { June } 20\end{array}$ & $\begin{array}{r}0.0 \\
1.0 \\
2.0 \\
3.0 \\
4.0 \\
5.0 \\
10.0 \\
15.0 \\
20.0 \\
25.0 \\
30.0 \\
32.0\end{array}$ & $\begin{array}{l}30.9 \\
30.9 \\
31.0 \\
30.9 \\
30.9 \\
31.1 \\
32.1 \\
32.3 \\
32.6 \\
32.6 \\
32.6 \\
32.6\end{array}$ & $\begin{array}{l}11.7 \\
11.8 \\
11.8 \\
11.8 \\
11.7 \\
10.9 \\
8.5 \\
7.5 \\
7.2 \\
7.2 \\
7.2 \\
7.2\end{array}$ \\
\hline $\begin{array}{l}1 \\
1 \\
1 \\
1 \\
1 \\
1 \\
1 \\
1 \\
1 \\
1 \\
1 \\
1 \\
1\end{array}$ & $\begin{array}{l}\text { June } 21 \\
\text { June } 21 \\
\text { June } 21 \\
\text { June } 21 \\
\text { June } 21 \\
\text { June } 21 \\
\text { June } 21 \\
\text { June } 21 \\
\text { June } 21 \\
\text { June } 21 \\
\text { June } 21 \\
\text { June } 21 \\
\text { June } 21\end{array}$ & $\begin{array}{r}0.0 \\
1.0 \\
2.0 \\
3.0 \\
4.0 \\
5.0 \\
10.0 \\
15.0 \\
20.0 \\
25.0 \\
30.0 \\
35.0 \\
37.4\end{array}$ & $\begin{array}{l}29.6 \\
29.6 \\
29.5 \\
29.5 \\
29.6 \\
29.7 \\
30.6 \\
31.3 \\
31.5 \\
32.5 \\
32.6 \\
32.6 \\
32.6\end{array}$ & $\begin{array}{l}12.7 \\
12.7 \\
12.7 \\
12.7 \\
12.6 \\
12.5 \\
11.2 \\
10.0 \\
9.5 \\
7.4 \\
7.2 \\
7.2 \\
7.2\end{array}$ \\
\hline $\begin{array}{l}2 \\
2 \\
2 \\
2 \\
2 \\
2 \\
2 \\
2 \\
2 \\
2 \\
2 \\
2\end{array}$ & $\begin{array}{l}\text { June } 20 \\
\text { June } 20 \\
\text { June } 20 \\
\text { June } 20 \\
\text { June } 20 \\
\text { June } 20 \\
\text { June } 20 \\
\text { June } 20 \\
\text { June } 20 \\
\text { June } 20 \\
\text { June } 20 \\
\text { June } 20\end{array}$ & $\begin{array}{r}0.0 \\
1.0 \\
2.0 \\
3.0 \\
4.0 \\
5.0 \\
10.0 \\
15.0 \\
20.0 \\
25.0 \\
30.0 \\
33.0\end{array}$ & $\begin{array}{l}30.8 \\
30.8 \\
30.8 \\
30.8 \\
31.0 \\
31.0 \\
31.8 \\
32.0 \\
32.6 \\
32.6 \\
32.6 \\
32.6\end{array}$ & $\begin{array}{r}12.2 \\
12.2 \\
12.2 \\
12.2 \\
12.1 \\
12.0 \\
9.7 \\
8.4 \\
7.3 \\
7.2 \\
7.2 \\
7.2\end{array}$ \\
\hline $\begin{array}{l}2 \\
2 \\
2 \\
2\end{array}$ & $\begin{array}{l}\text { June } 21 \\
\text { June } 21 \\
\text { June } 21 \\
\text { June } 21\end{array}$ & $\begin{array}{l}0.0 \\
1.0 \\
2.0 \\
3.0\end{array}$ & $\begin{array}{l}29.5 \\
29.5 \\
29.4 \\
29.5\end{array}$ & $\begin{array}{l}12.8 \\
12.7 \\
12.8 \\
12.7\end{array}$ \\
\hline
\end{tabular}


Iable E.1. (contd)

\begin{tabular}{|c|c|c|c|c|}
\hline Site \# & Date & $\begin{array}{c}\text { Depth, } \\
\text { m }\end{array}$ & $\begin{array}{c}\text { Salinity, } \\
\text { ppt } \\
\end{array}$ & $\frac{\text { Temperature, }}{{ }^{\circ} \mathrm{C}}$ \\
\hline $\begin{array}{l}2 \\
2 \\
2 \\
2 \\
2 \\
2 \\
2 \\
2\end{array}$ & $\begin{array}{l}\text { June } 21 \\
\text { June } 21 \\
\text { June } 21 \\
\text { June } 21 \\
\text { June } 21 \\
\text { June } 21 \\
\text { June } 21 \\
\text { June } 21\end{array}$ & $\begin{array}{r}4.0 \\
5.0 \\
10.0 \\
15.0 \\
20.0 \\
25.0 \\
30.0 \\
31.5\end{array}$ & $\begin{array}{l}29.5 \\
29.6 \\
30.7 \\
31.6 \\
32.0 \\
32.5 \\
32.6 \\
32.5\end{array}$ & $\begin{array}{r}12.7 \\
12.6 \\
11.5 \\
9.5 \\
8.6 \\
7.4 \\
7.3 \\
7.3\end{array}$ \\
\hline $\begin{array}{l}3 \\
3 \\
3 \\
3 \\
3 \\
3 \\
3\end{array}$ & $\begin{array}{ll}\text { June } 19 \\
\text { June } 19 \\
\text { June } 19 \\
\text { June } 19 \\
\text { June } 19 \\
\text { June } 19 \\
\text { June } 19\end{array}$ & $\begin{array}{r}0.0 \\
1.0 \\
2.0 \\
3.0 \\
4.0 \\
5.0 \\
10.3\end{array}$ & $\begin{array}{l}31.7 \\
31.7 \\
31.1 \\
32.2 \\
32.5 \\
32.5 \\
32.5\end{array}$ & $\begin{array}{l}9.6 \\
9.4 \\
9.3 \\
8.0 \\
7.3 \\
7.3 \\
7.3\end{array}$ \\
\hline $\begin{array}{l}4 \\
4 \\
4 \\
4 \\
4 \\
4 \\
4 \\
4 \\
4\end{array}$ & $\begin{array}{l}\text { June } 18 \\
\text { June } 18 \\
\text { June } 18 \\
\text { June } 18 \\
\text { June } 18 \\
\text { June } 18 \\
\text { June } 18 \\
\text { June } 18 \\
\text { June } 18\end{array}$ & $\begin{array}{l}0.0 \\
1.0 \\
2.0 \\
3.0 \\
4.0 \\
5.0 \\
6.0 \\
7.0 \\
8.0\end{array}$ & $\begin{array}{l}30.6 \\
30.6 \\
30.7 \\
30.8 \\
30.7 \\
30.7 \\
30.8 \\
30.8 \\
30.8\end{array}$ & $\begin{array}{l}10.5 \\
10.5 \\
10.3 \\
10.2 \\
10.2 \\
10.2 \\
10.1 \\
10.1 \\
10.2\end{array}$ \\
\hline $\begin{array}{l}5 \\
5 \\
5 \\
5 \\
5 \\
5 \\
5 \\
5\end{array}$ & $\begin{array}{l}\text { June } 21 \\
\text { June } 21 \\
\text { June } 21 \\
\text { June } 21 \\
\text { June } 21 \\
\text { June } 21 \\
\text { June } 21 \\
\text { June } 21\end{array}$ & $\begin{array}{l}0.0 \\
1.0 \\
2.0 \\
3.0 \\
4.0 \\
5.0 \\
6.0 \\
9.5\end{array}$ & $\begin{array}{l}29.7 \\
29.7 \\
29.5 \\
29.2 \\
29.2 \\
29.1 \\
29.0 \\
28.7\end{array}$ & $\begin{array}{l}12.0 \\
12.0 \\
12.0 \\
12.0 \\
12.0 \\
12.0 \\
12.0 \\
12.0\end{array}$ \\
\hline
\end{tabular}




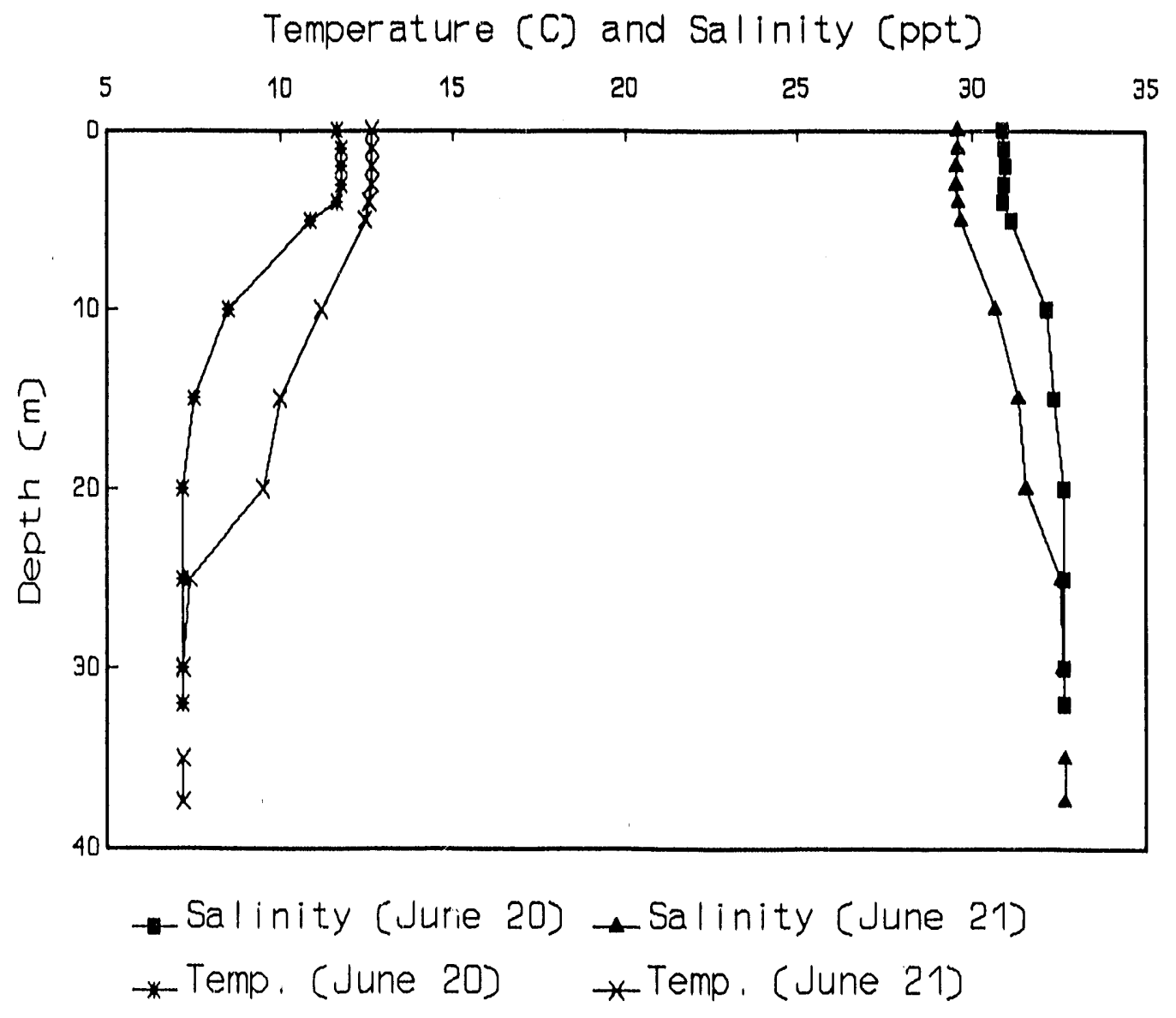

FIGURE E.1. Hydrographic Data from the Southwest Ocean Disposal Site Collected on June 20 and 21, 1991 


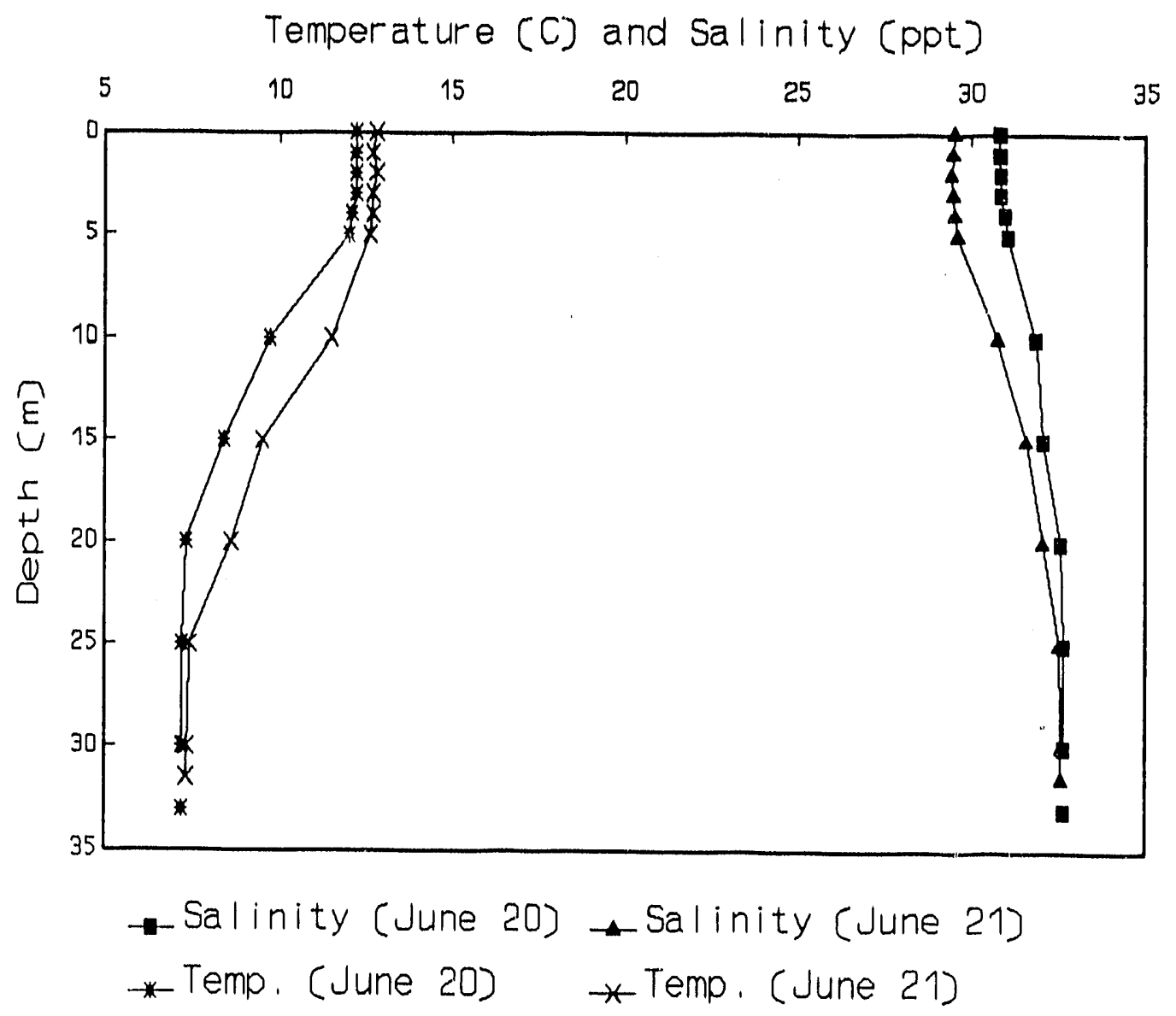

EIGURE E.2. Hydrographic Data from the North Reference Area Collected on June 20 and 21, 1991

E.4 


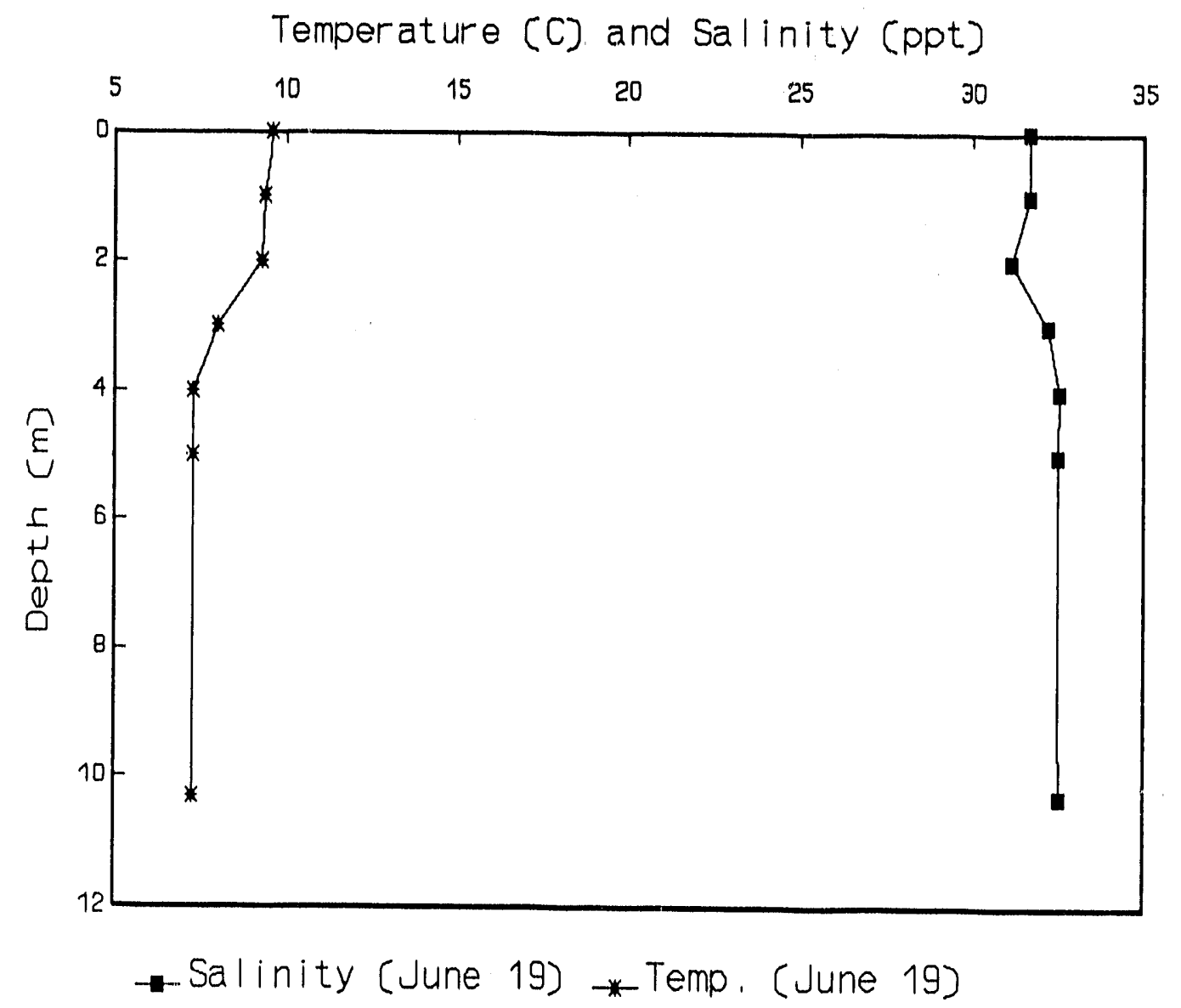

FIGURE E.3. Hydrographic Data from the Proposed South Beach Site Collected on June 19, 1991

\section{E. 5}




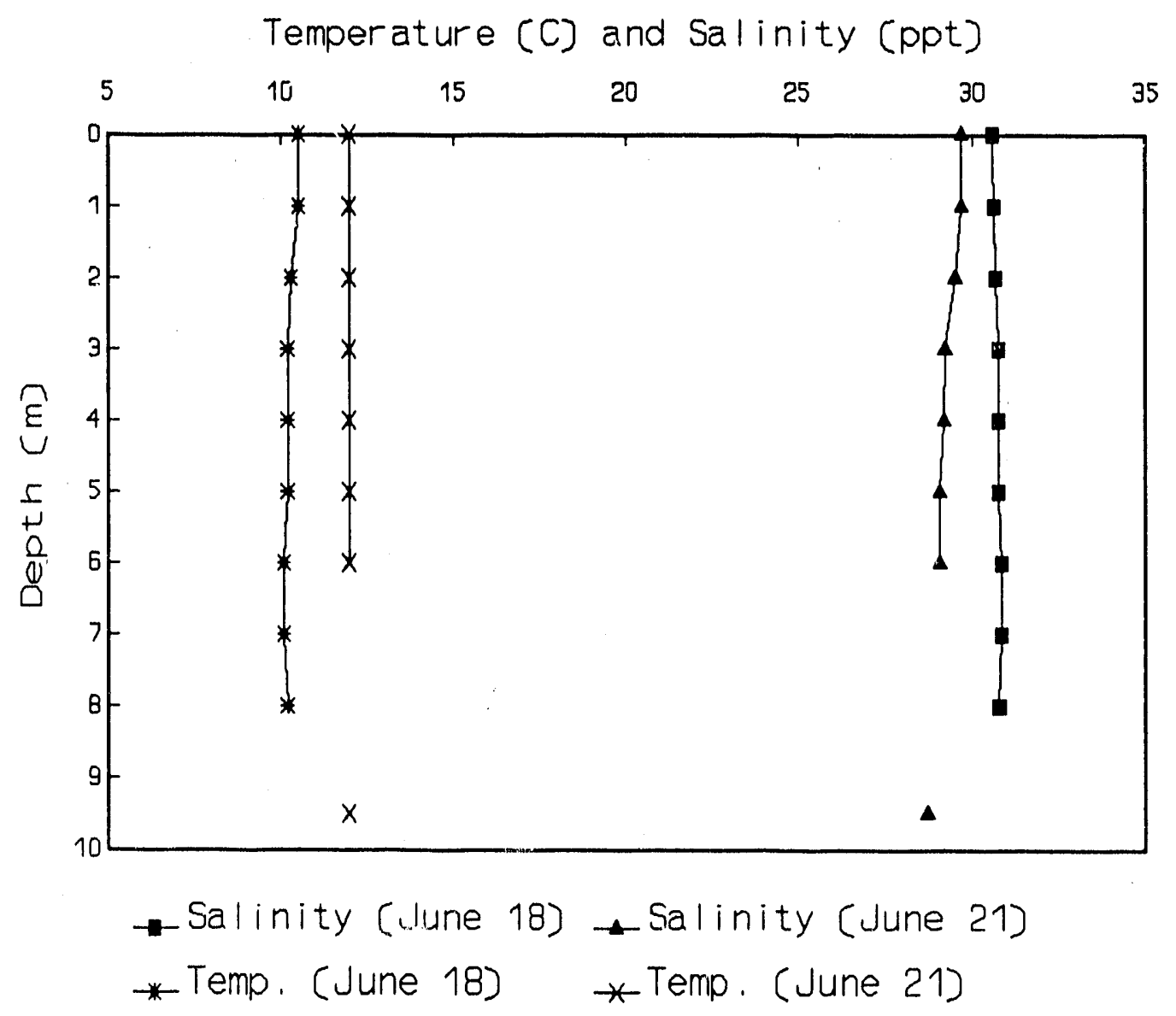

FIGURE E.4. Hydrographic Data from Grays Harbor Entrance Collected on June 18 and 21, 1991 at the Half Moon Bay and North Entrance Sites, Respectively 


\section{DISTRIBUTION}

No. of

Copies

OFFSITE

2 DOE/Office of Scientific and Technical Information

10 Bert Brun

U.S. Army Corps of Engineers 4735 E. Marginal Way South Seattle, WA 98134
No. of

Copies

ONSITE

18 Pacific Northwest Laboratory

L. D. Antrim (5)

V. I. Cullinan

R. M. Ecker

J. W. Falco

M. J. Graham

P. C. Hays

W. H. Pearson

R. L. Skaggs

Publishing Coordination

Technical Report Files 

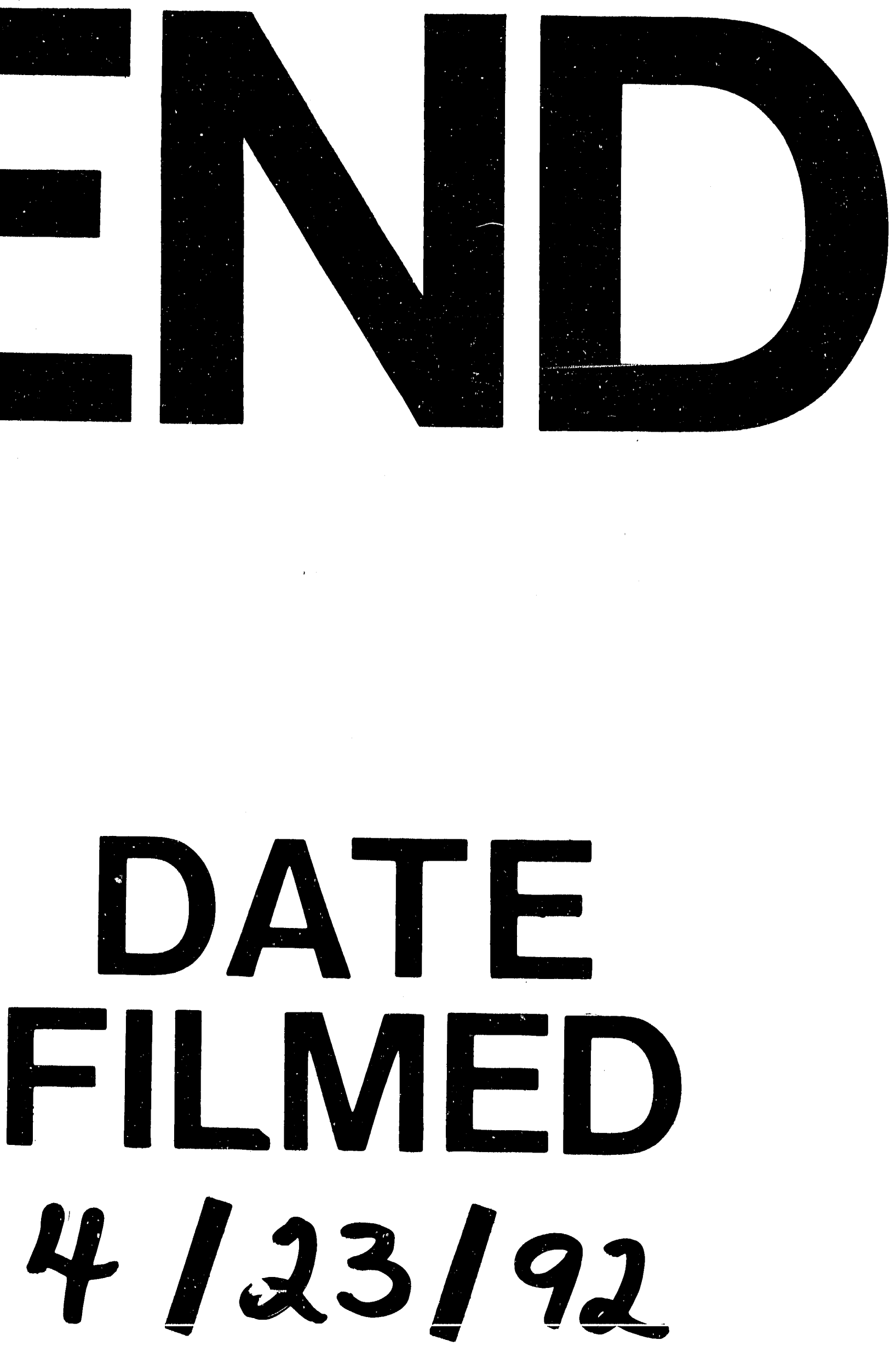
